\title{
Where do we go? VC firm heterogeneity and the exit routes of newly listed high-tech firms
}

Diego Useche

Université de Rennes 1

CREM-CNRS \& Faculté des Sciences Economiques

7, Place Hoche CS 86514

35065 Rennes Cedex - FRANCE

Phone number: $+33(0) 223233596$

Fax: +33 (0) 299388084

e-mail: diego.useche@univ-rennes1.fr

Sophie Pommet

Université Nice Sophia Antipolis

GREDEG- UMR CNRS 7321

UCA, Nice, France.

Phone number: $+33(0) 493954396$

Fax: +33 (0) 299388084

e-mail: Sophie.POMMET@unice.fr

\section{Small Business Economics (Forthcoming)}

"This is a pre-print of an article published in Small Business Economics. The definitive publisher-authenticated version Useche, D., Pommet, S. Small Bus Econ

https://doi.org/10.1007/s11187-020-00351-x is available online at:

https://doi.org/10.1007/s11187-020-00351-x"

\section{Acknowledgments:}

Previous drafts of this paper have benefited from helpful discussion and comments of colleagues at CREM- Université de Rennes 1, Université Paris 1 Panthéon-Sorbonne, EU-SPRI ECC Milan Conference 2017 and DRUID 2018. In particular, we would like to thank Vincenzo Butticè, Jesper Lindgaard Christensen, Jean-François Sattin, Maarten Rabijns and Ellsa Ughetto. We wish also thank the editor (Enrico Santarelli) and two anonymous referees for very valuable inputs and suggestions. This work was supported by a Post-doc Fellowship to DU from the French State in the frame of the Bordeaux IdEx "Investments for the Future" program (ANR-10-IDEX-03-02) and received a financial support from Université Paris 1 Panthéon-Sorbonne. 


\title{
Where do we go? VC firm heterogeneity and the exit routes of newly listed high-
} tech firms

\begin{abstract}
In this paper, we study how the support of heterogeneous venture capital firms (VCs), that is: independent venture capital firms (IVCs), bank-affiliated venture capital firms (BVCs) and corporate venture capital firms (CVCs), shapes the delisting route of companies through business failure and merger \& acquisitions (M\&As), while distinguishing between European M\&As and extra-EU M\&As after the Initial Public Offering (IPO). We find that the influence of the VCs in the firms' post-IPO delisting varies according to the mode of delisting and the type of venture capitalist. In particular, we find that the presence of leading IVC and BVC investments before IPO is related to a lower likelihood of exiting the stock market through business failure but does not significantly affect the likelihood of M\&As. In contrast, the presence of CVC investors is related to a higher likelihood of delisting through extra-EU M\&As.
\end{abstract}

Keywords: IPO survivability, Independent venture capital, Corporate venture capital, Bankaffiliated venture capital, High-tech firms, Firm failure, Cross-border M\&As

JEL classification: G24; G30 


\section{INTRODUCTION}

Analyzing high-tech firms' survival and exit routes has been a preoccupation of finance and management scholars (Cefis and Marsili 2012; Useche 2015; Wagner and Cockburn 2010, among others) for some time. While a large number of studies suggest that the involvement of venture capital firms (VCs) influences the strategy and performance of their portfolio companies, few studies have analyzed the impact of $\mathrm{VC}$ investors on the survival and exit routes after initial public offering (IPO) of their portfolio companies (Chou et al. 2013; Jain and Kini 2000; Manigart et al. 2002). The links between different types of VCs and the firm exit route after the IPO, remain relatively unexplored. The literature on VCs generally argues that VCs provide their portfolio companies with a complex bundle of value-adding activities (Lee et al. 2011; Luukkonen et al. 2013; Megginson et al. 2016). VC investors represent more than a financial source for small and medium-sized high-tech companies, they also provide value-adding effects by "coaching" their portfolio, providing monitoring, management support and access to professional networks (Bertoni et al. 2013b; Sørensen 2007). They engage in face-to-face interactions with managers, are involved in the boards of their portfolio companies (Arikan and Capron 2010; Fitza et al. 2009), in the recruitment of top managers and in their strategy development (De Clercq et al. 2006; Hellmann and Puri 2002). Thus, VCs may provide their portfolio companies with many competitive resources (e.g., reputation, knowledge, support and connections), which persist with the firm after the IPO and become part of its stock of resources, shaping long-term firm performance (Arikan and Capron 2010). Moreover, there is evidence that VCs may be extensively involved in firms after the IPO (see for instance: Barry et al. 1990; Gill and Walz 2016) and thus continue to influence the firm's strategic decisions after the IPO (Goergen et al. 2009; Krishnan et al. 2011).

Even though the influence of venture capitalists in the life-cycle of their portfolio firms is recognized, their role in post-IPO exit routes remains poorly understood. Jain and Kini (2000), for example, found evidence that VC involvement improves the survival profile of IPO-issuing firms. VC-backed firms are found to be better performing and less likely to exit from the stock market through failure (Chou et al. 2013; Jain and Kini 2000), although some 
evidence suggests that VC support increases the probability of delisting through merger and acquisitions (M\&As) (Arikan and Capron 2010; Brau et al. 2010; Gill and Walz 2016). However, most VC literature does not distinguish between the different modes of exit postIPO (Chou et al. 2013) and only in a few cases has started to analyze how the characteristics of VC providers shape firm survival in specific markets (Manigart et al. 2002).

The contribution of our paper is twofold. First, this paper investigates the influence of different types of leading VCs on the post-IPO exit routes of newly listed European high-tech companies. An emerging body of literature explores how different dimensions of VC heterogeneity influence the strategy and performance of their portfolio companies. As explained by Colombo and Murtinu (2017), one of the most important dimensions of heterogeneity among VCs is the type of ownership and governance. Captive VCs are structured as investment vehicles or business units of the parent company (Bertoni et al. 2013a; Tykvová 2006). The parent company can be a nonfinancial company, a financial intermediary (bank), or a government body. Thus, the group of captive VCs includes corporate venture capital firms (CVCs), bank-affiliated venture capital firms (BVCs) and governmental venture capital firms (GVCs). In contrast, independent venture capital firms (IVCs) manage several pools of capital provided by various sources and are organized as limited partnerships. We focus on three of the main types of VCs: IVCs, BVCs and CVCs. We excluded the group of GVC-backed companies, composed of only 6 observations. It has been found that the organizational structure of leading ${ }^{1} \mathrm{VC}$ providers influences their strategic objectives, level of involvement, and hence, their portfolio companies' performance (Bottazzi et al. 2008; Tykvová 2007). While there is an emerging body of literature on the impact of different types of VCs on the performance of their portfolio firms (Alperovych et al. 2015; Bertoni et al. 2013a; Colombo and Murtinu 2017; Cumming et al. 2017; Ivanov and Xie 2010), little research has been conducted on their influence on aftermarket survival. We aim to contribute to this literature by exploring how the leading VCs' type influences the type of delisting of newly listed European high-tech companies.

Second, this paper takes into account two types of exit routes from the stock market: i) business failure and ii) M\&A. It is usually claimed that bankruptcy and voluntary delisting are

\footnotetext{
${ }^{1}$ It is commonly accepted that leading VC investors, which make the earliest and/or the largest investment to support the new venture before IPO, are more influential, and provide activities that add more value than the other investing VCs (Barry et al. 1990; Lee et al. 2011; Lee and Wahal 2004). We defined the leading VC as the $\mathrm{VC}$ with the largest investment in the last round before the date of the IPO.
} 
forms of business failure ${ }^{2}$, while acquisition has a more complex interpretation (Wagner and Cockburn 2010). The literature has shown that mechanisms driving M\&As are different from those behind other types of exit (Balcaen et al. 2012; Cefis and Marsili 2012; Wagner and Cockburn 2010). However, there little evidence on the factors which facilitate different forms of acquisitions and how different VC investors might affect them. We aim to shed new light on the role of different types of venture capitalists in post-IPO acquisitions by disentangling two types of acquisitions, namely intra-EU and extra-EU deals. We classified firms' delistings as intra-EU M\&As if the IPO firms were acquired/merged by an acquirer located within Europe and we classified firms' delistings as extra-EU deals if the IPO firms were acquired/merged by a foreign company located outside of Europe.

For this paper, we built an original database linking data from five main sources: i) the EURIPO database ${ }^{\circledR}$ (managed by Universoft) for IPO information, ii) VentureSource ${ }^{\circledR}$ (owned by Dow Jones) for VC investments before IPO, iii) Migliorati and Vismara (2014) European Underwriter for information on reputations, iv) the Orbit patent database ${ }^{\circ}$, and $v$ ) the Amadeus database ${ }^{\circledR}$ (from Bureau van Dijk) for financial and complementary information. We assembled a sample of 651 high-tech companies that went public on French, German, and British stock markets between 1995 and 2012. We focus on high-tech European companies for two main reasons. First, they are knowledge-intensive companies commonly faced with a high risk of failure due to technology and market uncertainty. Second, high-tech companies are also more likely to enjoy the complex bundle of value-adding activities and competitive resources that different types of VCs might provide.

We found that the presence of leading IVCs or BVCs before IPO is related to a lower likelihood of exit from the stock market through business failure, while the presence of CVCs is related to a higher likelihood of exit from the stock market through extra-EU M\&As. We also found that the VCs' reputation, measured by the past market share of VC-backed IPOs, does not impact the probability of delisting, while the presence of a lead foreign VC investor reduces the probability of delisting through business failure.

\footnotetext{
2 The literature has shown that there are differences between voluntary delisting and bankruptcy which are both forms of firm failure. Voluntary liquidation takes place when asset proceeds are sufficient to repay all liabilities (Balcaen et al. 2011). In contrast, a bankruptcy is typically forced by creditors or a court as a result of a firm's failure to fulfill payments (Balcaen et al. 2011). Therefore, a company undergoing a voluntary liquidation might favor a delisting through acquisition.
} 
The paper is organized as follows. In Section 2, we review the relevant literature on the way heterogeneous investors' endorsements can influence post-IPO survival (subsection 2.1) and the type of delisting (subsection 2.2) among high-tech IPOs in Europe. We derive a number of hypotheses to be tested. Section 3 describes the data and variables. Section 4 presents the methodology and the regression results. Section 5 discusses the main results and concludes.

\section{LITERATURE AND HYPOTHESES}

\subsection{VC governance and firm's type of delisting after the IPO}

A number of papers have addressed the determinants of the decision to delist, the time and the exit route from the stock market (Balcaen et al. 2011; Bharath and Dittmar 2010; De and Jindra 2012; Kashefi Pour and Lasfer 2013; Oh 2018, among others). These studies have shown that companies delist for several reasons and in diverse forms such as bankruptcy, voluntary liquidation and M\&A. A distressed company might go bankrupt, for instance, if it is not able to generate enough profits (Wagner and Cockburn 2010). It might also voluntarily delist due to difficulties in raising additional funds or due to high levels of debt (Kashefi Pour and Lasfer 2013). It might also become an acquisition target because of imminent bankruptcy (Balcaen et al. 2012; De and Jindra 2012). The type of delisting might result from a strategic or an involuntary choice (see for instance: Bharath and Dittmar 2010; Kashefi Pour and Lasfer 2013). Bharath and Dittmar (2010), for example, suggest that firms delist from the stock market when the cost-benefit trade-off of staying in the market is no longer in favor of the IPO company. If the costs that arise from staying on the market exceed the benefits, then the company can choose or be forced to delist. These costs are for instance administrative costs, organizational and unanticipated costs or indirect costs related to agency conflicts (Kashefi Pour and Lasfer 2013) or those related to corporate governance issues (Gill and Walz 2016).

Some studies have focused on the cohort of young high-tech firms that went public during the stock market bubble in the US (Mehran and Peristiani 2010; Peristiani and Hong 2004; Wagner and Cockburn 2010) and Europe (Audretsch and Lehmann 2005; Useche 2015). In general, firms with robust entry characteristics are found to be more viable and have longer survival times. In line with the industrial organization and innovation studies, the most common result is that younger and smaller firms exhibit higher delisting rates while the firms' 
human capital, innovation and intellectual property assets are positively related to the length of time the firm survives on the stock market before being delisted or censored (Audretsch and Lehmann 2005; Peristiani and Hong 2004; Useche 2015; Wagner and Cockburn 2010). In the same vein, some studies have shown that the ownership and corporate governance of companies are determinants for their post-IPO survival (see among others: Audretsch and Lehmann 2005; Gounopoulos and Pham 2018).

Turning to the role of venture capitalists in the fate of firms post-IPO, Jain and Kini (2000), for example, found evidence that the presence of VCs prior to going public improves the survival prospects of newly listed firms. In a related study, Audretsch and Lehmann (2005) found that the investment share of VCs prior to IPO is negatively related to delisting rates. Evidence from US IPOs shows that the reputation of VCs influences post-issue survivability (Chou et al. 2013). These authors found that IPOs backed by prestigious VCs are less likely to delist for performance failure and have longer listing duration relative to those without VC backing. The authors point out that IPOs backed by ordinary venture capitalists are as likely to delist as IPOs without VC backing (see also: Krishnan et al. 2011). Despite the interest of this approach, it fails to consider that firm delistings can take different forms (Balcaen et al. 2011; Cefis and Marsili 2012; Useche 2015) and post-IPO delisting can be shaped differently depending on the types of VCs.

We argue here that the corporate governance of VCs influences the competitive resources provided to their portfolio firms and thus can impact the exit channel of these firms from the stock market. Although a complete analysis of the differences in VC corporate governance as related to firm performance and behavior is beyond the scope of this paper, we provide some key insights here and refer the reader to Alperovych et al. (2015), Bertoni et al. (2013a), Bottazzi et al. (2008), Cumming et al. (2017), Tykvová (2006) and Alvarez-Garrido and Dushnitsky (2016), among others, for more detail.

There is evidence that the corporate governance structure of VCs also matters in long-term performance when analyzing the objectives they pursue (Arikan and Capron 2010). For example, the main objective of IVCs is a financial one, this implies that they need to add value to their portfolio companies in order to generate return and cash to their primary investors. In contrast, CVCs are seen as strategic investors and are typically good at providing in-depth technological support to firms (Colombo and Murtinu 2017; Dushnitsky and Lenox 
2006). CVCs often pursue strategic objectives in addition to the financial ones (Benson and Ziedonis 2009, 2010; Dushnitsky and Lenox 2006) while BVCs seem in general to be more interested in finding complementarities with their lending activities (Hellmann et al. 2008). By the same token, Manigart, De Waele, et al. (2002) show that IVCs require higher rates of return than captive VCs, and that this behavior is associated with more intense involvement and a shorter expected investment holding period. Empirical studies tend to confirm that these differences in the competencies of VCs exist in the European market. For example, based on European VC deals, Bertoni et al. (2015) find that BVC investors employ more passive strategies than other VC types, and are more inclined to invest in older and larger companies than their counterparts. They also find that BVCs are more specialized in short-term investments than other VC types. In the same vein, for a set of European countries, Bottazzi et al. (2008) show that IVCs and CVCs are more involved in their companies than both GVCs and BVCs. They also found that this higher level of involvement of IVCs and CVCs is positively related to the success of their portfolio companies.

The literature also widely recognizes that among the different types of VC investors, IVCs and CVCs add more value and increase the competitive advantage of their portfolio companies (Bottazzi et al. 2008; Colombo and Murtinu 2017; Ivanov and Xie 2010; Tykvová 2006). Colombo and Murtinu (2017) find that both IVCs and CVCs boost the economic performance of their portfolio companies. However, as explained by Ivanov and Xie (2010) and Colombo and Murtinu (2017), the effect of CVCs on companies is not straightforward because it depends on the strategic positioning of the parent company. In comparison with both IVC and CVC investors, BVCs have less capacity to provide technological support and value-adding services (Andrieu 2013).

We may expect that differences in the types of VCs might influence the firm's post-IPO survival. While IVCs may reduce the risk of exit from the stock market through their valueadding behavior, captive VCs may shape aftermarket behavior depending on the strategic positioning of the parent company. For example, when considering the role of CVCs, two opposite impacts on survival may emerge: the first is that CVC-backed companies may strongly benefit from the knowledge of the industry, technology and networks of their parent firm, which may influence the probability of making the portfolio company a valuable acquisition target, increasing its probability of exiting the stock market through an M\&A. 
Conversely, CVCs' superior capabilities of nurturing innovation may allow their companies to survive longer on the market.

Simply examining how VC corporate governance influences post-IPO survival, does not take into account how different types of VCs may affect different types of delisting. It can hide any influence various VCs might have in increasing the likelihood of valuable firms delisting through M\&As. For example, even if it seems that IVCs are better positioned than CVCs to facilitate the funded companies' long-term survival after IPO, CVCs may facilitate the exit from the stock market of their portfolio companies through more valuable M\&As.

\subsection{Delisting through a failure and the type of $\mathrm{VC}$ investor}

A rich body of industrial organization, finance and strategic management literature has provided theoretical and empirical evidence of the link between entry/IPO characteristics and firm failure. Indeed, the risk of failure has been shown to be shaped by firm-specific characteristics, such as experience (Audretsch 1995), financial riskiness (Ritter 1991; Schultz 1993), entry mode and size, among others (Agarwal and Audretsch 2001; Audretsch et al. 1999; Cefis and Marsili 2006; Santarelli and Vivarelli 2007), but also by the presence of specific investors as VCs (Arikan and Capron 2010).

Drawing insights from an emerging body of literature studying firm survival and the determinants of delisting on one hand (Balcaen et al., 2012; Bennett and Snyder, 2017; Cefis and Marsili, 2012) and VC corporate governance on the other hand (Alperovych et al. 2015; Croce et al. 2015; Cumming et al. 2017), we relate the type of venture capitalist to the risk of delisting through failure.

By analyzing the role of VCs in the survival of IPOs, Chou et al. (2013) suggest that VCs might offer poor guidance in terms of IPO timing. In this context, the "grandstanding hypothesis" proposed by Gompers (1996) may have direct implications for post-IPO delisting. Rushing firms to IPO too early harms firm quality, increasing underpricing and reducing future growth opportunities (Lee and Wahal, 2004). VCs and more especially IVCs can be tempted to push their portfolio prematurely in order to build their reputation, which may also increase firm failure. Compared to CVC and BVC investors, young IVC investors have strong incentives to "grandstand" by taking their portfolio companies public earlier than more 
established venture capitalists, in order to enhance their own reputation, thereby increasing funding from private investors (Bertoni et al. 2013a; Chahine and Goergen 2011; Gompers 1996). In contrast, VC firm experience has been found to be associated with larger valueadding capacities (Berger and Schaeck 2011; Nahata 2008; Sørensen 2007). Experienced VCs select companies with higher potential (Sørensen 2007), raise funds more easily (Nahata 2008) and provide better advisory services and monitoring (Berger and Schaeck 2011).

The literature on VC corporate governance also suggests important differences in the competitive resources that different types of VCs may provide to their portfolio companies, shaping long-term performance and firm delisting through failure. As already explained, it has been found that different types of VCs vary in their capabilities to add value to their portfolio companies. Studies show that in general, IVCs that are more active in the governance of their companies offer also higher value-adding support. According to Bottazzi et al. (2008), BVC investors are among the least active investors and thus are also less able to improve the performance of their companies in the long run compared to IVC investors and, to a lesser extent, to CVC investors.

However, it has also been argued that the main interest of BVCs as investors is to alleviate the risk of financial distress of their portfolio companies. Indeed, as explained by Hellmann et al. (2008), banks use VC investments to build lending relationships. The results obtained by Megginson et al. (2016) on a sample of US IPO firms, suggest that VC-backed IPOs have a lower risk of financial distress than their non-VC-backed counterparts and that this impact is higher for BVC-backed companies when comparing them with IVC-backed companies. For a sample of small and micro European firms, Croce et al. (2015), find that after the investment, BVC-backed firms exhibit a significant increase in debt exposure, compared to non-invested firms. However, the authors cannot say whether the risk of financial distress translates into real default events.

Furthermore, the literature also suggests important differences in the ability of venture capitalists to nurture innovation. This impact of VCs on a firm's innovation performance is important because it has been shown that the innovative activity of IPOs is a determinant in their ability to survive on the market (Wagner and Cockburn, 2010). CVCs have been shown to be better than both IVCs and BVCs in nurturing innovation because their unique organizational and compensation structure may allow them to have a longer-term investment 
horizon (Chemmanur et al. 2014a). A firm's innovative capabilities improve long-term performance and shape a firm's exit decisions (Cefis and Marsili 2012, 2019). Chemmanur et al. (2014b) found that compared to IVC-backed firms, CVC-backed firms are more innovative, younger, riskier and less profitable. However, the authors also suggest that CVCs are better able to nurture innovation because of the technological fit of their parent companies with the entrepreneurial firms they back and because of their greater tolerance for failure compared with their IVC counterparts. By consequence, the risk of failure of CVC-backed firms might be reduced through the CVCs' support and expertise in innovation but at the same time might be increased through higher risk taking and greater failure tolerance of CVCs. Therefore, we hypothesize here that:

H1: IVC- and BVC-backed firms, and to lesser extent CVC-backed firms, exhibit a lower risk of delisting through business failure compared to non-VC-backed companies.

\subsection{Delisting through M\&As and the type of VC investor}

Finance and organization studies shed light on how VCs are related to M\&As for IPO companies (Balcaen et al. 2012; Brau et al. 2010; Gill and Walz 2016). The vast majority of academic literature on M\&As for IPO companies has mainly focused on the determinants of post-IPO acquisitions without disentangling different types of deals. When analyzing different types of M\&As, the literature has shown that cross-border acquirers compared to their domestic peers faced exacerbated information asymmetries and risks due to a limited monitoring capacity and potential lack of knowledge of the target and the host country's environment, legal system, business practices, and culture (Boschma et al. 2016; Ragozzino 2009; Useche et al. 2019). In this context, we offer a new perspective arguing that the role of VCs in post-IPO acquisitions might depend on the nature of the venture capitalist supporting the company and the type of M\&A. We distinguish here between EU acquisitions (called also intra-EU M\&As) and extra-EU acquisitions that are by definition cross-border deals. Indeed, as already shown by Bertrand and Zitouna (2008), there are similarities between European and domestic acquisitions due to European economic integration. Thus, distinguishing between intra- and extra-EU deals is more appropriate in order to understand the forces at stake. We consider first the impact of VCs in post-IPO acquisition in a general way, by 
referring to (intra-EU) M\&As and we then develop the arguments considering cross-border M\&As (CBM\&As), as in the case of extra-EU deals.

The literature has identified several types of assets and characteristics that make firms more likely to become acquisition targets shortly after their IPO (Jain and Kini 2000; Brau et al 2010; De and Jindra 2012; Chemmanur et al. 2014b). However, these studies have little to say on differences across domestic and cross-border transactions. Overall, it has been found that successful firms, but not necessarily the most successful, are more likely to become acquisition targets after going public. De and Jindra (2012) found that IPO targets are stronger performers than companies which delist due to bankruptcy and they resemble firms that survive following their IPOs. Jain and Kini (2000) and Brau et al. (2010), for instance, show that US IPO firms introduced by prestigious investment bankers are more likely to be acquired than fail. Brau et al. (2010) found also that larger, high-tech, and bubble-year firms have a higher propensity to be acquired after going public. These authors also explain that selling the company after going public might be considered as a dual-track strategy that helps entrepreneurs to increase their harvest value. Indeed, this strategy allows high-tech companies to reduce the problem of asymmetric information (Chemmanur et al. 2014b) by pricing the value of a firm's intangible assets (Brau et al., 2010). For high-tech companies, studies show that patents are considered to be more easily identifiable and transferable intangible assets that increase the likelihood of a firm being an acquisition target after IPO (Useche 2015; Wagner and Cockburn 2010).

When it comes to the role of VCs, the existing literature often provides positive results regarding the role of VCs' support in post-IPO acquisitions, with the issues of VC governance and distinct forms of M\&As remaining unexplored. We argue that VCs may positively influence the likelihood of acquisition of their portfolio companies for different reasons: first, the value-adding functions of VCs might increase the company's performance and its attractiveness as a valuable acquisition target. Second, the monitoring and screening functions of $\mathrm{VC}$ investors might also help acquirers to identify valuable acquisition targets. It is often argued that VCs operate as intermediaries certifying the quality of their portfolio, which reduces informational asymmetries and increases the attractiveness of their portfolio companies as acquisition targets. In this perspective, Gill and Walz (2016) show that US VCbacked IPO firms are more likely to delist via a takeover process when they are financed by experienced and reputable VCs. The authors suggest that this finding supports the 
certification hypothesis of VCs in post-IPO acquisitions. Taken as a whole, IVCs and CVCs have been found to add more value and provide better monitoring and screening functions to their portfolio companies compared to BVCs, which in turn might favor their attractiveness as acquisition targets. However, when analyzing the certification services provided by the different types of VCs at IPO, there is no such consensus ${ }^{3}$. Last, VCs might provide their portfolio companies access to a professional network, increasing their visibility to potential bidders. Hochberg et al. (2007) found that better-networked VCs, which are also more experienced, perform better at selling or making public their portfolio companies. These authors found that IVCs use their co-investment network to support the sale of their portfolio companies, while according to Chemmanur et al. (2014a) and Ivanov and Xie (2010), CVCs use the marketing, distribution and research arms of their parent companies. Thus, considering these arguments we hypothesize here that:

H2a: IVC- and CVC-backed firms, and to lesser extent BVC-backed firms, exhibit a higher risk of delisting through EU M\&As compared to non-VC-backed companies.

As already emphasized, there are diverse causes and forms of M\&A deals. Here, we focus on CBM\&As (extra-EU deals) which are those involving a foreign acquirer and are widely used by multinational companies to source technologies and gain access to valuable foreign markets (Hagedoorn and Duysters 2002; Jovanovic and Rousseau 2008; Ruckman 2005). CBM\&As allow the acquirers to obtain access to the target firms' production capabilities and intangible assets including, among others, highly skilled human capital and local networks (Meyer et al. 2011; Ranft and Lord 2002). The acquisition of a technology company (distressed or not) can provide the acquirer with an important competitiveness instrument to strengthen internal technological and innovation capabilities (Benson and Ziedonis 2009, 2010; Graebner 2004; Ruckman 2005). However, the acquisition may also represent a risky challenge because the acquirer may find it difficult to value and assimilate the technological resources and capabilities obtained through the acquisition (Benson and Ziedonis 2009).

\footnotetext{
${ }^{3}$ Most of the literature on different types of VCs and certification relates to their work at IPO and offers mixed results depending on the characteristics of the different VCs and the countries of analysis. For instance, based on US data, Dolvin et al. (2007) find that BVCs are superior to IVCs in providing certification services during the going-public process. Along the same line, Wang and Wan (2013) find that compared to IVCs, CVCs are more able to certify the quality of US firms during the IPO process. In the case of European countries (UK, France and Germany), Rindermann (2003) shows that there is no uniform evidence indicating systematic differences in the certification role between the different types of VCs.
} 
Studies on CBM\&As have shown that cross-border acquirers undergo a "double lemon" problem as they have lower monitoring capacity and are less well-informed on target characteristics due to accounting, legal and institutional differences across countries (Bertrand and Zitouna 2008). However, cross-border acquirers use both their internal and external networks to identify and spot acquisition opportunities (Cantwell 2013; Johanson and Vahlne 2009; Useche et al. 2019) and usually pay higher prices relative to domestic M\&As (Shimizu et al. 2004). In this case, third-party signals might be important to identify relevant and valuable knowledge assets as acquisition targets in cross-border transactions. For instance, Cattaneo et al. (2015) found that firms affiliated with prestigious and internationalized thirdparty signals such as universities are more prone to be targeted in CBM\&As because the affiliation with a prestigious university is expected to increase the technological capabilities and network opportunities of the affiliated firm.

In this perspective, venture capitalists have been found to play a positive role in attracting cross-border acquirers (see for instance; Cattaneo et al. 2015; Jääskeläinen and Maula 2014). However, previous studies have shown that VCs are not all equal in promoting the international activities of their portfolio companies. Researches have shown that cross-border VCs (Jääskeläinen and Maula 2014; Mäkelä and Maula 2005) and CVCs (Park and LiPuma 2020) are the most powerful VCs improving the internationalization of their portfolio companies. We argue that the role of VCs in CBM\&As might also depend on the type of VC corporate governance. We especially focus here on the role of CVCs because, compared with both IVCs and BVCs, CVCs provide to their portfolio with a complex bundle of resources which might attract foreign acquirers such as quick access to markets, technical assistance and product recognition through the marketing, distribution and research arms of their parent companies (Chemmanur, al. 2014a; Ivanov and Xie 2010). Indeed, CVCs are part of multinational companies with an extensive global network of partners (Park and LiPuma 2020) which might attract foreign acquirers. CVCs might convey better information on the innovation capabilities of their portfolio companies and send a stronger signal of the quality of the target to an acquirer especially in highly risky deals like CBM\&As (Chemmanur et al. 2014a; Gill and Walz 2016). By providing innovation support, product recognition and marketing and distribution networks, CVCs might be more able than other types of VCs to reduce informational asymmetries and bring confidence to potential foreign acquirers. Moreover, as explained by Chemmanur et al. (2014a), CVCs have greater technology knowledge but they have also greater industry knowledge than other VCs. This deep 
knowledge of both technology and industry may make CVCs also more able than other VCs to seek out potential (international) buyers for the IPO firm. Finally, because CVC-backed firms are in general more innovative than other VC-backed firms, CVCs may be more prone than other VCs to use a dual-track strategy.

Following these arguments we hypothesize here that:

$\mathrm{H} 2 \mathrm{~b}$ : CVC-backed firms exhibit a higher risk of delisting through CBM\&As compared to other types of VCs and to non-VC-backed companies.

\section{DATA AND VARIABLES}

\subsection{Data}

We built an original database linking data from five main sources: i) the EURIPO database ${ }^{\circledR}$ (managed by Universoft) for IPO information, ii) VentureSource® (owned by Dow Jones) for VC investments before IPO, iii) Migliorati and Vismara's (2014) European underwriters for reputation rankings, and iv) the Orbit patent database ${ }^{\circledR}$, and v) the Amadeus database ${ }^{\circledR}$ (from Bureau van Dijk) for additional financial and complementary information. From the EURIPO database, we selected a sample of high-tech companies that went public between 1995 and 2012 on the stock markets of the three largest European economies: France, Germany, and the United Kingdom. For France, we considered the Paris Bourse up to 2004 and Euronext afterwards (primary and secondary markets); for Germany, we considered the Deutsche Börse; and for the United Kingdom, we considered the London Stock Exchange (AIM and Official List). The EURIPO database ${ }^{\circledR}$ is managed by Universoft, a University of Bergamo (Italy) spin-off. According to the description in Vismara et al. $(2012)^{4}$, EURIPO contains data (derived from offering prospectuses) for more than 5,000 companies that went public in Europe since 1985. VentureSource ${ }^{\circledR}$ (owned by Dow Jones) is one of the most comprehensive databases on VC investments. From Venture Source, we obtained information on the VCs' characteristics, and additional information on VC financing that was missing from EURIPO. Both Venture Source and EURIPO are highly reliable and correlated in terms

\footnotetext{
${ }^{4}$ See Cogliati et al. (2011) and Vismara et al. (2012) for detailed information on the composition of the EURIPO database.
} 
of VC investments. In order to obtain information on the patenting activity of IPO companies, we used the Orbit patent database ${ }^{\circledR} 5$.

Finally, the EURIPO database provides the motivations for delisting up to December 2010. Then, we added information on company delistings after December 2010. We tracked firms' delistings up to the end of November 2015 using the Amadeus database ${ }$, stock market documents, and web searches to identify the companies that were acquired or which failed after IPO (see Appendix 1 for more details on database consolidation). We also used the Amadeus database ${ }^{\circledR}$ to supply additional accounting information.

In order to select the companies that operate in innovative industries, we focused on two broadly defined high-tech sectors using the Industry Classification Benchmark (ICB) provided by Euronext: health care (including health care equipment and services, pharmaceuticals and biotechnology) and information and communication technology (software, internet, computer services, telecom, technology hardware and equipment). The final sample includes 651 companies over the period 1995-2012 (see Table 1).

\section{--- Include Table 1 here ---}

\subsection{Variables}

\subsubsection{Firm exit from the stock market as the dependent variable}

Firm survival is understood as its continuous listing on the stock market after IPO, during the period of analysis (Hensler et al. 1997; Useche 2015; Wagner and Cockburn 2010). Our survival approach makes use of two types of dependent variables: survival time in the sample (in months) which is defined as the difference between the effective delisting date and the effective date of the IPO, and a binary variable indicating the firm's mode of delisting (competing risk specification). Survival time is right-censored to the end of November 2015 and thus, we track firms' exit from the stock market for all active firms up to the end of November 2015. We used the EURIPO database as our main source of information about delisting. The EURIPO database classifies the delisting of IPOs into three groups: Bankruptcy or direct request of the company, Imposed - pursuant to a rule of the market, and Merger/Take

\footnotetext{
${ }^{5}$ Orbit is a patent database which allows users to build and organize patent portfolios, and examine individual patents. The Orbit patent database ${ }^{\circledR}$ has developed a family definition (FamPat) which provides comprehensive family coverage of worldwide patent publications.
} 
over. Thus, we classified a delisting as firm failure if the firm was in the first two categories. We also classified a delisting as an M\&A if the firm was merged or acquired and we distinguished between EU deals and extra-EU deals. We classified firms' delistings as EU acquisitions (called also intra-EU M\&As) if the IPOs were acquired/merged by an acquirer located within Europe (122 cases) and we classified firms' delistings as extra-EU deals if the IPOs were acquired/merged by a foreign company located outside of Europe (63 cases $)^{6}$. The US is the most important location for acquirers outside of Europe (55 cases) while UnitedKingdom is the most important location for acquirers within Europe (53 cases), followed by France (29 cases) and Germany (24 cases). These four countries account for $87 \%$ of acquisitions in our sample.

\subsubsection{VC organizational structure}

Venture Source provides information on the parent companies of VCs, which allows us to identify the type of VC. When information was missing from Venture Source, we supplemented it by consulting the VCs' websites. Independent $V C$ is defined as a dummy variable that is equal to 1 if the lead VC investor before IPO was an IVC, and zero otherwise. Bank-affiliated $V C$ is defined as a dummy variable that is equal to 1 if the lead VC investor before IPO was a subsidiary company of a bank, and zero otherwise. Corporate VC is defined as a dummy variable that is equal to 1 if the parent company of the lead VC firm before IPO was a non-financial firm, and zero otherwise. The VC lead was defined as the VC with the largest investment in the last round before the date of the IPO.

Following Coakley et al. (2007), we introduced a variable Number of VCs, which accounts for the VCs' syndicating behavior. It considers the quality of VC monitoring, and the number of venture capitalists holding equity stakes at IPO. We also used a $V C$ reputation variable, which accounts for the reputation of VCs in the sample. This variable is measured by the VC's relative market share of completed VC-backed IPOs (Chou et al. 2013; Nahata 2008). The VC's relative market share of IPOs controls for differences in the quality of value-adding services. We also included for the presence of foreign VC investors in the capital of the company at the time of IPO. Foreign $V C$ is defined as a dummy variable that is equal to 1 if

\footnotetext{
${ }^{6}$ Intra-EU M\&As includes domestic acquisitions (e.g., a French company buying in France), as well as cross-border acquisitions within Europe (e.g., a French company buying in Germany or the UK). Extra-EU M\&As includes companies outside of Europe buying European companies (e.g., a US company buying in Germany or the UK).
} 
the lead VC operates in a different country from the portfolio company's home country, and zero otherwise (Mäkelä and Maula 2005).

\subsection{Controls}

\subsubsection{Underwriter reputation}

An important control to reduce the risk of alternative explanations is to consider the reputation of the IPO underwriters, which is traditionally seen as an important organizational endorsement at IPO. High-tech companies going public in Europe usually select local underwriters or "national champion" banks (Migliorati and Vismara 2014). IPO underwriters act as certifying agents that provide data which reduces information asymmetries between firm insiders and outsiders. The literature shows that more reputable underwriters are associated with a better ability to screen companies, higher issuer quality, and less speculative issues (Fernando et al. 2005; Migliorati and Vismara 2014). We used the underwriter ranks from Migliorati and Vismara (2014), which are estimated based on EURIPO data and the market share of lead underwriters (Megginson and Weiss 1991). We introduced an Underwriter Reputation variable, which is defined as the underwriter reputation measured by equally weighted market shares based on the number of IPOs managed. The equally weighted ranking gives higher visibility to local banks which were the underwriters for many European IPOs.

\subsubsection{Firm size, experience and intangible assets}

We controlled for two important variables influencing IPO performance over the long term (Cefis and Marsili 2012; Megginson et al. 2016; Megginson and Weiss 1991; Useche 2015; Wagner and Cockburn 2010). We controlled for company size by including a log-transformed variable of total assets (Total assets) in the year preceding IPO (adjusted for inflation). We included a log-transformed variable for company age (Age at IPO) calculated as the difference between the effective date of the IPO and the date of legal incorporation. ${ }^{7}$

We also included the number of patent applications submitted by the firm in the five years before the IPO (Patent 5 years). The purpose of this time window is to take account of the

\footnotetext{
7 When the date of incorporation was not available in the EURIPO database, we obtained it from Venture Source, Amadeus database ${ }^{\circledR}$, or company websites.
} 
fact that recent patents provide the most up-to-date information about the firm's inventive capabilities at the time of the IPO (Heeley et al. 2007; Useche 2014).

\subsubsection{Industry segments, stock market effects, and market conditions}

We included three dummy variables for whether the company is quoted on the London (GB), Euronext (FR) or Frankfurt (DE) stock markets, and seven dummies for the firms' industry segment (see table 1). We also included dummy variables for the year of IPO (Year FE).

Finally, since IPOs tend to come in waves, we introduced two market condition controls Sector entry ratio and Dot-com bubble. The variable Sector entry ratio is measured as the number of high-tech companies going public per sector using the one digit-ICB classification, divided by the total number of high-tech IPOs in a given year. The variable Dot-com bubble is equal to 1 if the company was quoted in 1999 or 2000, and is zero otherwise.

We also controlled for the amount of money the firms raised during the IPO process. The IPO proceeds is defined as the log-transformed variable of the amount of money raised during the IPO process divided by the company's total assets the year preceding IPO. The amount of money the firm raises during the IPO process is a good indicator of the success of the IPO and thus, it can have an impact on the probability the firm has of surviving on the market.

\section{ECONOMETRIC STRATEGY AND RESULTS}

\subsection{Methodology}

To test our hypotheses and analyze the determinants of firms' survival, we used a Cox proportional hazard (PH) regression model (Cox 1972; Cox and Oakes 1998). As explained by Cleves et al. (2016), the hazard function in this model measures the instantaneous failure rate at time $t$ given that the individual survives until $t$. The Cox hazard regression is a semiparametric approach that makes no assumptions about the baseline hazard rate, and therefore, is more robust than parametric methods.

This model expresses the exit rate to a destination state as a rather simple function of observed and unobserved explanatory variables and the elapsed duration in the current state. 
Survival time is usually defined as a non-negative random $T$, the failure rate at time $t$ and the hazard function $h(t)$ is defined as the limit:

$$
h_{(t)}=\operatorname{Lim}_{t \rightarrow 0} \frac{p(t \leq T<t+t \mid T \geq t)}{t}
$$

The different survival models are estimated using a vector of covariates for the firms' entry characteristics at IPO and the regression coefficients, which are estimated from the data. Thus, the hazard function of a firm $i$ is expressed as:

$$
h\left(t \mid \mathrm{x}_{\mathrm{i}}\right)=h_{0}(t) e^{\left(\beta_{k} X_{i}\right)}
$$

In this expression, ho is an arbitrary and unspecified baseline hazard function reflecting the probability of an event conditional on the firm having survived until time $t$ after its IPO. The Cox regression uses the $\mathrm{PH}$ assumption, which assumes that all groups of firms face a hazard function of the same shape. The Cox model assumes that the hazard functions of any two firms with different values on one or more covariates differ only by a factor of proportionality (Box-Steffensmeier and Zorn 2001). See Appendix 2 for a test to detect the correct model specification and proportionality assumption. We find no evidence that our specifications violate the $\mathrm{PH}$ assumption.

As noted above, we can also observe different modes of delisting: firms can be delisted as a result of failure, or cease trading as the result of an M\&A or a CBM\&A. We report estimation results for the competing risk model, which explicitly takes into account the firms' different modes of delisting ${ }^{8}$. See Appendix 2 for a test of the independence of exits (competing risk specification). Finally, as a robustness check, we also present the results for the Weibull duration model. The results are similar to the ones obtained from the Cox PH model (see Table 2A in Appendix 3).

\subsection{Descriptive statistics}

\footnotetext{
${ }^{8}$ Our model specifications include robust variance estimates with an added adjustment for clustering at the stock market level.
} 
Before presenting the results of the multivariate analyses, we present some descriptive statistics of our sample and variables. Our sample contains 651 companies that went public on French, German, and British stock markets during the period 1995-2012. It includes 206 VCbacked companies, and 445 non-VC-backed companies. Among the VC-backed companies, 155 were financed by IVCs, 23 by CVCs and 28 by BVCs ${ }^{9}$. In Table 1 (presented above), we can see that IVCs are more present in the UK market while both BVCs and CVCs are more invested in the French markets. We also see that IVCs are more invested in the sectors of pharmaceutics and biotechnology than both BVCs and CVCs. In comparison, BVCs and CVCs are more invested in the IT sector (taken as a whole) than their IVC counterparts. Table 2 presents the descriptive statistics and correlation matrix of the main variables included in the analysis. Notice the high correlation between $V C$ Reputation and Independent $V C$. However, an examination of the variance inflation factors (VIFs) across types of exits from the stock market and for the complete sample finds no evidence of multicollinearity. VIFs are lower than 2.42 for the different types of VCs and lower than the conservative threshold of 4 for the other VC-related variables.

--- Include Table 2 here ---

Table 3 provides summary statistics for the variables. The companies are divided into subgroups depending on the type of lead VC investor. In columns 1 to 5, we present the mean value for each group. In addition, we conduct a standard two-sided t-test to test for differences in means between the subgroups using the non-VC group as the reference: non-VC versus VC (Column 2); non-VC versus IVC-backed firms (Column 3); non-VC versus CVC-backed firms (Column 4) and non-VC versus BVC-backed firms (Column 5). We also present the significance of two-sided t-test between types of VCs: IVC versus BVC, IVC versus CVC and BVC versus CVC (Columns 6, 7 and 8 respectively). We observe that VC-backed companies seem less likely to exit the stock market (p-value <0.001), own more patents (pvalue $<0.001)$ and are more successful at IPO ( $p$-value $<0.05)$. When we compare the three groups of VC-backed companies, we can see that the firms financed by BVC investors are less likely to exit the stock market within a shorter period of time than both IVC-backed (pvalue $<0.05$ ) and non-VC-backed firms (p-value $<0.001)$. We see also that the firms financed

\footnotetext{
${ }^{9}$ We excluded the group of GVC-backed companies composed of only 6 firms. The effect of GVC is not statistically significant in our econometric analysis for any form of exit and coefficients are similar to those presented. For the sake of brevity, the regressions are not included here and we limit our analysis to the group of CVC-, IVC- and BVC-backed firms. Results are available upon request.
} 
by CVC and IVC investors held more patents before the IPO when compared to non-VCbacked firms (p-value <0.001). Finally, it appears that BVCs are less reputable investors in the market compared to other VC investors ( $\mathrm{p}$-value $<0.05$ ).

--- Include Table 3 here ---

Figures 1 and 2 present the Kaplan-Meier survival curves for the firms in our sample. In our sample, 408 companies exited the market, of which 110 obtained VC financing.

First, when analyzing Figure 1, we can see that VC-backed companies have higher survival rates than non-VC-backed companies. We also find in Figure 2 that BVC-backed firms are associated with higher survival rates than both the companies with no VC financing and the ones financed by other types of VCs. Indeed, Figure 2 shows that the survival curve for BVCbacked companies is above the one for the other companies (IVC, CVC and non-VC-backed companies). However, and perhaps most importantly, these preliminary results can hide differences between $\mathrm{VC}$ investors in the modes of delisting followed by their portfolio companies. The multivariate analysis allows us to disentangle the effects for each group of firms.

--- Include Figures 1 and 2 here ---

\subsection{Results of the multivariate analysis}

In Table 4 the results of the multivariate analysis are reported for pooled and competing risk models (Cox specifications), which we take as our base model. In Column 1, we show the estimation results from the pooled model, which does not distinguish between modes of delisting. In Columns 2, 3 and 4, we present the results from the competing risk models which distinguish between delisting due to business failure (Column 2) and delisting due to intra-EU M\&As (Column 3) and extra-EU M\&As (CBM\&As) (Column 4).

In line with the literature, we observe known effects for our control variables. We observe that innovative high-tech firms with a larger stock of patents before IPO are less likely to delist through business failure (Column 2). We find that older high-tech firms are less likely to delist from the stock market (Column 1) while larger companies and those that raise a 
significant amount of funds at the IPO are more likely to exit from the stock market due to extra-EU M\&As (Column 4). Surprisingly, we also find that being supported by a reputable underwriter before IPO does not significantly affect the hazard of delisting through business failure or intra-EU M\&As while it significantly diminishes the probability of the firm being acquired through extra-EU M\&As ${ }^{10}$.

Turning to the effect of the characteristics of the VCs, we observe very important differences in the hazards for different modes of delisting. First, the reputation of VCs (measured by the past market share of VC-backed IPOs) has no significant impact on the probability of exit from the stock market whatever the type of delisting ${ }^{11}$. Surprisingly, having a larger number of VCs involved in the financing increases the risk of delisting through failure aftermarket (Column 2) while no statistically significant effect is found on the hazard of delisting from the stock market via different types of M\&As. This result suggests that a larger size of syndication might be related to increased conflict of interest at the time of IPO which affects the long-term survival of IPOs. When analyzing the impact of the variable Foreign VC, our results in Column 2 show that the presence of a cross-border VC investor as leader in the capital of the company significantly reduces its probability of being delisted through a failure. This result indicates that foreign VCs can positively influence the performance of their portfolio companies. However, contrary to what we might have expected, Foreign VC does not significantly increase the likelihood of delisting from the stock market through a CBM\&A.

In relation to the effects of our main variables, the results suggest that the influence of the VC investors in the firms' delisting varies according to the mode of exit from the stock market and the type of venture capitalist. In Column 1, we show that when considering the pooled model, only IVC-backed firms have a lower probability of delisting from the stock market than their non-VC-backed peers. In Column 2, regression results suggest that high-tech firms financed by IVCs and BVCs are associated with a lower likelihood of delisting through a business failure while CVC-backed firms are not less likely to fail than their non-VC-backed

\footnotetext{
${ }^{10}$ In our robustness checks (available on request), we introduced underwriter reputation based on the amount of money raised by the underwriting firm at IPO (Migliorati and Vismara 2014). Regression results show that proceeds-weighted rankings of underwriter reputation are not statistically significant, suggesting that in Europe they do not affect the hazard of exit after IPO.

${ }^{11}$ In robustness checks, we considered the VC experience (which is calculated as the age of the leading VC firm at the time of the investment) as an alternative measure of $V C$ reputation. Regression results show that both measures do not affect the hazard of distinct modes of delisting after IPO. In addition, regression results are similar to those presented above. Results are available upon request.
} 
peers. Wald tests of the differences between coefficients reject the null hypothesis that BVCbacked companies are equal to CVC- or IVC-backed companies, and suggest that BVCbacked firms exhibit a lower risk of delisting through failure compared with other VC-backed firms. These results partially validate our hypothesis H1. The coefficients for our main three variables in Column 2 suggest that, compared to non-VC-backed high-tech companies, the ones supported by IVCs and BVCs are respectively 35\% and 69\% less likely to delist from the stock market due to business failure compared to their non-VC-backed peers.

In Columns 3 and 4, we explore the relationship between different types of VCs and M\&As, distinguishing respectively between intra-EU M\&As and extra-EU M\&As. In Column 3, the results indicate that high-tech firms backed by different types of VCs are as likely to be acquired by an intra-European acquirer than non-VC-backed peers. Therefore, we reject hypotheses $\mathrm{H} 2 \mathrm{a}$. In contrast, our results in Column 4 suggest that being financed by a CVC investor increases the probability that a company will delist from the stock market through an extra-EU M\&A by more than $200 \%$ (hazard ratio of 3.24) compared with its non-VC-backed peers. In contrast, being supported by leading IVCs and BVCs does not significantly affect the hazard of delisting through extra-EU M\&As. Thus, we validate our hypotheses $H 2 b^{12}$. Wald tests of the differences between coefficients reject the null hypothesis that CVC-backed companies are equal to IVC- or BVC-backed companies, and suggest that CVC-backed firms exhibit a higher likelihood of delisting through extra-EU M\&As compared with other VCbacked firms. This result suggests that CVCs increase the attractiveness of their portfolio companies as international acquisition targets after going public. This could also be related to a dual-track strategy aiming to increase the harvest value of their companies.

--- Include Table 4 here ---

\section{Conclusion and further research}

Venture capitalist support before IPO may have both positive and negative effects on a firm's

\footnotetext{
12 As an alternative distinction of M\&As, we distinguish between domestic (for instance an acquirer and a target both located in France) and CBM\&As (for instance an acquirer located in France and a target located in Germany). Regression results are similar to those presented above but the coefficient of Corporate VC is reduced to 0.892 , which is in line with the intuition that CVCs are particularly important to attract acquirers located in more distant countries. For the sake of brevity, the regressions have not been included but are available upon request.
} 
survival and delisting routes after IPO. VCs may provide many competitive resources before IPO, shaping a firm's entry characteristics, long-term performance and survival. Through selection and value-adding services, VCs may be related to longer survival of their portfolio companies. Conversely, the negative effects of venture capitalists may be the result of grandstanding and conflict of interest among VC investors.

This paper makes two major contributions. First, to the best of our knowledge, this is the first study that explores the different types of VCs and how they relate to the delisting channel of newly-listed high-tech companies in Europe. We focus on the types of VCs and we control for venture capitalists' reputation and foreignness, which are measures of VC heterogeneity and quality (Chou et al. 2013; Park and LiPuma 2020). Second, this paper takes into account two modes of exit from the stock market (i.e., business failure and M\&A) and disentangles differences in M\&As by focusing on intra-EU or extra-EU M\&As.

Our empirical results suggest that the presence of leading IVCs and BVCs before IPO is related to a lower likelihood of exiting from the stock market through a business failure while they do not affect the likelihood of M\&As (whether intra-EU or extra-EU M\&As). We also found that BVCs contribute to a lower risk of delisting through failure compared with other types of VCs. Our study also shows that the presence of CVCs is related to a significantly higher likelihood of delisting through extra-EU M\&As, but is not associated with a statistically significant reduction in the likelihood of failure or the likelihood of intra-EU M\&As. Contrary to the evidence found in the US, we found that the reputation of VCs, measured by the past market share of VC-backed IPOs, has no impact on the survival rates of companies after IPO. However, foreign VCs help firms to stay longer on the stock market by reducing the risk of delisting through business failure.

We have investigated some of the characteristics of VCs that affect exit routes of firms postIPO, but other features of VCs may have an impact on how VC nature affects the post-IPO exit routes of portfolio firms. For example, we can imagine that the type of professional network connections of different types of VCs can shape their ability to enhance the future success of a portfolio firm. This is especially true when considering the role of IVCs and CVCs in the exit behavior after IPO. Future research with a more comprehensive database may investigate this issue in order to analyze in greater depth the network connections of different types of VCs and their impact on exit routes after IPO. Future research might also 
investigate the role of different types of VCs and their characteristics by disentangling different forms of firm failure, for instance voluntary liquidation and bankruptcy. Moreover, it would also be interesting to explore if VCs are related to other types/rationales of M\&As after IPO. Further research might also investigate how different VC strategies to create value and reputation might influence the survival and type of delisting from the exchange. A limitation of our analysis is that we have restricted our sample to companies that went public. This choice might introduce a selection bias because CVC- and BVC-backed companies are less likely to go public (Kim and Park 2017; Park and LiPuma 2020). In addition, public companies might have significantly different characteristics and behaviors compared to private companies, reducing the generalizability of our results to those companies. Thus, future research might include private companies and consider how different types of VCs influence their exit behavior and how they differ from public companies.

Finally, our findings have implications for entrepreneurs and challenges for future research. Future research might explore whether the observed relationship between the type of VC and the mode of exit from the stock market depends not only on the characteristics of the VCs but also on the selection of VC partners by firms. For firms that base their value on technology development and look to harvest the return for their activities through merging or selling out to other firms, it is important to choose and attract the attention of CVC investors which might provide specific competencies and access to their networks to attract the attention of potential acquirers in more distant locations. For firms aiming to sustain their business and enjoy the stock market over time, being able to attract and select the appropriate VC partners is crucial.

\section{REFERENCES}

Agarwal, R., \& Audretsch, D. B. (2001). Does Entry Size Matter? The Impact of the Life Cycle and Technology on Firm Survival. Journal of Industrial Economics, 49(1), 21-43. https://doi.org/10.1111/1467-6451.00136

Alperovych, Y., Hübner, G., \& Lobet, F. (2015). How does governmental versus private venture capital backing affect a firm's efficiency? Evidence from Belgium. Journal of Business Venturing, 30(4), 508-525. https://doi.org/10.1016/j.jbusvent.2014.11.001

Alvarez-Garrido, E., \& Dushnitsky, G. (2016). Are entrepreneurial venture's innovation rates sensitive to investor complementary assets? Comparing biotech ventures backed by corporate and independent VCs: Comparing Biotech Ventures Backed by Corporate and Independent VCs. Strategic Management Journal, 37(5), 819-834. https://doi.org/10.1002/smj.2359 Andrieu, G. (2013). The Impact of the Affiliation of Venture Capital Firms: A Survey. Journal of Economic Surveys, 27(2), 234-246. https://doi.org/10.1111/j.1467- 
6419.2011.00702.x

Arikan, A. M., \& Capron, L. (2010). Do newly public acquirers benefit or suffer from their pre-IPO affiliations with underwriters and VCs? Strategic Management Journal, 31(12), 1257-1289. https://doi.org/10.1002/smj.861

Audretsch, D. B. (1995). Innovation and Industry Evolution. (Cambridge, MA: MIT Press.). Audretsch, D. B., \& Lehmann, E. E. (2005). The Effects of Experience, Ownership, and Knowledge on IPO Survival: Empirical Evidence from Germany. Review of Accounting and Finance, 4(4), 13-33. https://doi.org/10.1108/eb043435

Audretsch, D. B., Santarelli, E., \& Vivarelli, M. (1999). Start-up size and industrial dynamics: some evidence from Italian manufacturing. International Journal of Industrial Organization, 17(7), 965-983. https://doi.org/10.1016/S0167-7187(98)00002-2

Balcaen, S., Manigart, S., Buyze, J., \& Ooghe, H. (2012). Firm exit after distress: differentiating between bankruptcy, voluntary liquidation and M\&A. Small Business Economics, 39(4), 949-975. https://doi.org/10.1007/s11187-011-9342-7

Balcaen, S., Manigart, S., \& Ooghe, H. (2011). From distress to exit: determinants of the time to exit. Journal of Evolutionary Economics, 21(3), 407-446. https://doi.org/10.1007/s00191010-0192-2

Barry, C. B., Muscarella, C. J., Peavy, J. W., \& Vetsuypens, M. R. (1990). The role of venture capital in the creation of public companies. Journal of Financial Economics, 27(2), 447-471. https://doi.org/10.1016/0304-405X(90)90064-7

Bennett, V. M., \& Snyder, J. (2017). The Empirics of Learning from Failure. Strategy Science, 2(1), 1-12. https://doi.org/10.1287/stsc.2016.0020

Benson, D., \& Ziedonis, R. H. (2009). Corporate Venture Capital as a Window on New Technologies: Implications for the Performance of Corporate Investors When Acquiring Startups. Organization Science, 20(2), 329-351. https://doi.org/10.1287/orsc.1080.0386 Benson, D., \& Ziedonis, R. H. (2010). Corporate venture capital and the returns to acquiring portfolio companies. Journal of Financial Economics, 98(3), 478-499. https://doi.org/10.1016/j.jfineco.2010.07.003

Berger, A. N., \& Schaeck, K. (2011). Small and Medium-Sized Enterprises, Bank Relationship Strength, and the Use of Venture Capital. Journal of Money, Credit and Banking, 43(2-3), 461-490. https://doi.org/10.1111/j.1538-4616.2010.00381.x

Bertoni, F., Colombo, M. G., \& Grilli, L. (2013). Venture capital investor type and the growth mode of new technology-based firms. Small Business Economics, 40(3), 527-552. https://doi.org/10.1007/s11187-011-9385-9

Bertoni, F., Colombo, M. G., \& Quas, A. (2015). The patterns of venture capital investment in Europe. Small Business Economics, 45(3), 543-560. https://doi.org/10.1007/s11187-0159662-0

Bertoni, F., Ferrer, M. A., \& Martí, J. (2013). The different roles played by venture capital and private equity investors on the investment activity of their portfolio firms. Small Business Economics, 40(3), 607-633. https://doi.org/10.1007/s11187-011-9384-x

Bertrand, O., \& Zitouna, H. (2008). Domestic versus cross-border acquisitions: which impact on the target firms' performance? Applied Economics, 40(17), 2221-2238.

https://doi.org/10.1080/00036840600949397

Bharath, S. T., \& Dittmar, A. K. (2010). Why Do Firms Use Private Equity to Opt Out of Public Markets? Review of Financial Studies, 23(5), 1771-1818.

https://doi.org/10.1093/rfs/hhq016

Boschma, R., Marrocu, E., \& Paci, R. (2016). Symmetric and asymmetric effects of proximities. The case of M\&A deals in Italy. Journal of Economic Geography, 16(2), 505535. https://doi.org/10.1093/jeg/lbv005

Bottazzi, L., Darin, M., \& Hellmann, T. (2008). Who are the active investors? Evidence from venture capital. Journal of Financial Economics, 89(3), 488-512. 
https://doi.org/10.1016/j.jfineco.2007.09.003

Box-Steffensmeier, J. M., \& Zorn, C. J. W. (2001). Duration Models and Proportional Hazards in Political Science. American Journal of Political Science, 45(4), 972.

https://doi.org/10.2307/2669335

Brau, J. C., Sutton, N. K., \& Hatch, N. W. (2010). Dual-track versus single-track sell-outs: An empirical analysis of competing harvest strategies. Journal of Business Venturing, 25(4), 389402. https://doi.org/10.1016/j.jbusvent.2008.10.009

Cantwell, J. (2013). Blurred boundaries between firms, and new boundaries within (large multinational) firms: The impact of decentralized networks for innovation. Seoul Journal of Economics, 26(1), 1-32.

Cattaneo, M., Meoli, M., \& Vismara, S. (2015). Cross-border M\&A of biotech firms affiliated with internationalized universities. The Journal of Technology Transfer, 40(3), 409-433. https://doi.org/10.1007/s10961-014-9349-8

Cefis, E., \& Marsili, O. (2006). Survivor: The role of innovation in firms' survival. Research Policy, 35(5), 626-641. https://doi.org/10.1016/j.respol.2006.02.006

Cefis, E., \& Marsili, O. (2012). Going, going, gone. Exit forms and the innovative capabilities of firms. Research Policy, 41(5), 795-807. https://doi.org/10.1016/j.respol.2012.01.006 Cefis, E., \& Marsili, O. (2019). Good times, bad times: innovation and survival over the business cycle. Industrial and Corporate Change. https://doi.org/10.1093/icc/dty072 Chahine, S., \& Goergen, M. (2011). VC Board Representation and Performance of US IPOs. Journal of Business Finance \& Accounting, 38(3-4), 413-445. https://doi.org/10.1111/j.14685957.2011.02240.x

Chemmanur, T. J., Loutskina, E., \& Tian, X. (2014a). Corporate Venture Capital, Value Creation, and Innovation. Review of Financial Studies, 27(8), 2434-2473.

https://doi.org/10.1093/rfs/hhu033

Chemmanur, T. J., Signori, A., \& Vismara, S. (2014b). Two Stage Exits: An Empirical Analysis of the Dynamic Choice between IPOs and Acquisitions by European Private Firms. SSRN Electronic Journal. https://doi.org/10.2139/ssrn.2530987

Chou, T.-K., Cheng, J.-C., \& Chien, C.-C. (2013). How useful is venture capital prestige? Evidence from IPO survivability. Small Business Economics, 40(4), 843-863. https://doi.org/10.1007/s11187-011-9389-5

Cleves, M. A., Gould, W., \& Marchenko, Y. V. (2016). An introduction to survival analysis using Stata (Revised third edition.). College Station, Texas: Stata Press.

Coakley, J., Hadass, L., \& Wood, A. (2007). Post-IPO Operating Performance, Venture Capital and the Bubble Years. Journal of Business Finance \& Accounting, 34(9-10), 14231446. https://doi.org/10.1111/j.1468-5957.2007.02055.x

Cogliati, G. M., Paleari, S., \& Vismara, S. (2011). IPO pricing: growth rates implied in offer prices. Annals of Finance, 7(1), 53-82. https://doi.org/10.1007/s10436-010-0170-6 Colombo, M. G., \& Murtinu, S. (2017). Venture Capital Investments in Europe and Portfolio Firms' Economic Performance: Independent Versus Corporate Investors: Venture Capital Investments in Europe and Portfolio Firms' Economic Performance. Journal of Economics \& Management Strategy, 26(1), 35-66. https://doi.org/10.1111/jems.12170

Cox, D. R. (1972). Regression Models and Life-Tables. Journal of the Royal Statistical Society. Series B (Methodological), 34(2), 187-220.

Cox, D. R., \& Oakes, D. (1998). Analysis of survival data (1. CRC Press reprint.). Boca Raton: Chapman \& Hall/CRC.

Croce, A., D'Adda, D., \& Ughetto, E. (2015). Venture capital financing and the financial distress risk of portfolio firms: How independent and bank-affiliated investors differ. Small Business Economics, 44(1), 189-206. https://doi.org/10.1007/s11187-014-9582-4

Cumming, D. J., Grilli, L., \& Murtinu, S. (2017). Governmental and independent venture capital investments in Europe: A firm-level performance analysis. Journal of Corporate 
Finance, 42, 439-459. https://doi.org/10.1016/j.jcorpfin.2014.10.016

De Clercq, D., Fried, V. H., Lehtonen, O., \& Sapienza, H. J. (2006). An Entrepreneur's Guide to the Venture Capital Galaxy. Academy of Management Perspectives, 20(3), 90-112. https://doi.org/10.5465/amp.2006.21903483

De, S., \& Jindra, J. (2012). Why newly listed firms become acquisition targets. Journal of Banking \& Finance, 36(9), 2616-2631. https://doi.org/10.1016/j.jbankfin.2012.06.006 Dolvin, S. D., Mullineaux, D. J., \& Pyles, M. K. (2007). The impact of bank venture capital on initial public offerings. Venture Capital, 9(2), 145-164.

https://doi.org/10.1080/13691060601185417

Dushnitsky, G., \& Lenox, M. J. (2006). When does corporate venture capital investment create firm value? Journal of Business Venturing, 21(6), 753-772.

https://doi.org/10.1016/j.jbusvent.2005.04.012

Fernando, C. S., Gatchev, V. A., \& Spindt, P. A. (2005). Wanna Dance? How Firms and Underwriters Choose Each Other. The Journal of Finance, 60(5), 2437-2469.

https://doi.org/10.1111/j.1540-6261.2005.00804.x

Fitza, M., Matusik, S. F., \& Mosakowski, E. (2009). Do VCs matter? the importance of owners on performance variance in start-up firms. Strategic Management Journal, 30(4), 387-404. https://doi.org/10.1002/smj.748

Gill, A., \& Walz, U. (2016). Are VC-backed IPOs delayed trade sales? Journal of Corporate Finance, 37, 356-374. https://doi.org/10.1016/j.jcorpfin.2016.01.007

Goergen, M., Khurshed, A., \& Renneboog, L. (2009). Why are the French so different from the Germans? Underpricing of IPOs on the Euro New Markets. International Review of Law and Economics, 29(3), 260-271. https://doi.org/10.1016/j.irle.2009.02.006

Gompers, P. A. (1996). Grandstanding in the venture capital industry. Journal of Financial Economics, 42(1), 133-156. https://doi.org/10.1016/0304-405X(96)00874-4

Gounopoulos, D., \& Pham, H. (2018). Specialist CEOs and IPO survival. Journal of Corporate Finance, 48, 217-243. https://doi.org/10.1016/j.jcorpfin.2017.10.012

Graebner, M. E. (2004). Momentum and serendipity: how acquired leaders create value in the integration of technology firms. Strategic Management Journal, 25(89), 751-777.

https://doi.org/10.1002/smj.419

Grambsch, P. M., \& Therneau, T. M. (1994). Proportional hazards tests and diagnostics based on weighted residuals. Biometrika, 81(3), 515-526. https://doi.org/10.1093/biomet/81.3.515

Hagedoorn, J., \& Duysters, G. (2002). External Sources of Innovative Capabilities: The Preferences for Strategic Alliances or Mergers and Acquisitions. Journal of Management Studies, 39(2), 167-188. https://doi.org/10.1111/1467-6486.00287

Heeley, M. B., Matusik, S. F., \& Jain, N. (2007). Innovation, Appropriability, And The Underpricing Of Initial Public Offerings. Academy of Management Journal, 50(1), 209-225. https://doi.org/10.5465/amj.2007.24162388

Hellmann, T., Lindsey, L., \& Puri, M. (2008). Building Relationships Early: Banks in Venture Capital. Review of Financial Studies, 21(2), 513-541. https://doi.org/10.1093/rfs/hhm080 Hellmann, T., \& Puri, M. (2002). Venture Capital and the Professionalization of Start-Up Firms: Empirical Evidence. The Journal of Finance, 57(1), 169-197.

https://doi.org/10.1111/1540-6261.00419

Hensler, D. A., Rutherford, R. C., \& Springer, T. M. (1997). The survival of Initial Public Offerings in the aftermarket. Journal of Financial Research, 20(1), 93-110.

https://doi.org/10.1111/j.1475-6803.1997.tb00238.x

Hochberg, Y. V., Ljungqvist, A., \& Lu, Y. (2007). Whom You Know Matters: Venture

Capital Networks and Investment Performance. The Journal of Finance, 62(1), 251-301. https://doi.org/10.1111/j.1540-6261.2007.01207.x

Ivanov, V. I., \& Xie, F. (2010). Do Corporate Venture Capitalists Add Value to Start-Up Firms? Evidence from IPOs and Acquisitions of VC-Backed Companies. Financial 
Management, 39(1), 129-152. https://doi.org/10.1111/j.1755-053X.2009.01068.x

Jääskeläinen, M., \& Maula, M. (2014). Do networks of financial intermediaries help reduce local bias? Evidence from cross-border venture capital exits. Journal of Business Venturing, 29(5), 704-721. https://doi.org/10.1016/j.jbusvent.2013.09.001

Jain, B. A., \& Kini, O. (2000). Does the Presence of Venture Capitalists Improve the Survival Profile of IPO Firms? Journal of Business Finance <html_ent glyph=“@amp;"

ascii=“\&amp; "/> Accounting, 27(9\&10), 1139-1183. https://doi.org/10.1111/14685957.00350

Johanson, J., \& Vahlne, J.-E. (2009). The Uppsala internationalization process model revisited: From liability of foreignness to liability of outsidership. Journal of International Business Studies, 40(9), 1411-1431. https://doi.org/10.1057/jibs.2009.24

Jovanovic, B., \& Rousseau, P. L. (2008). Mergers as Reallocation. Review of Economics and Statistics, 90(4), 765-776. https://doi.org/10.1162/rest.90.4.765

Kashefi Pour, E., \& Lasfer, M. (2013). Why do companies delist voluntarily from the stock market? Journal of Banking \& Finance, 37(12), 4850-4860.

https://doi.org/10.1016/j.jbankfin.2013.08.022

Keele, L. (2010). Proportionally Difficult: Testing for Nonproportional Hazards in Cox Models. Political Analysis, 18(2), 189-205. https://doi.org/10.1093/pan/mpp044

Kim, J. Y. (Rose), \& Park, H. D. (2017). Two Faces of Early Corporate Venture Capital Funding: Promoting Innovation and Inhibiting IPOs. Strategy Science, 2(3), 161-175. https://doi.org/10.1287/stsc.2017.0032

Krishnan, C. N. V., Ivanov, V. I., Masulis, R. W., \& Singh, A. K. (2011). Venture Capital Reputation, Post-IPO Performance, and Corporate Governance. Journal of Financial and Quantitative Analysis, 46(5), 1295-1333. https://doi.org/10.1017/S0022109011000251 Lee, P. M., Pollock, T. G., \& Jin, K. (2011). The contingent value of venture capitalist reputation. Strategic Organization, 9(1), 33-69. https://doi.org/10.1177/1476127011400505 Lee, P. M., \& Wahal, S. (2004). Grandstanding, certification and the underpricing of venture capital backed IPOs. Journal of Financial Economics, 73(2), 375-407.

https://doi.org/10.1016/j.jfineco.2003.09.003

Luukkonen, T., Deschryvere, M., \& Bertoni, F. (2013). The value added by government venture capital funds compared with independent venture capital funds. Technovation, 33(45), 154-162. https://doi.org/10.1016/j.technovation.2012.11.007

Mäkelä, M. M., \& Maula, M. V. J. (2005). Cross-border venture capital and new venture internationalization: An isomorphism perspective. Venture Capital, 7(3), 227-257. https://doi.org/10.1080/13691060500258877

Manigart, S., Baeyens, K., \& Van Hyfte, W. (2002). The survival of venture capital backed companies. Venture Capital, 4(2), 103-124. https://doi.org/10.1080/13691060110103233 Manigart, S., De Waele, K., Wright, M., Robbie, K., Desbrières, P., Sapienza, H. J., \& Beekman, A. (2002). Determinants of required return in venture capital investments: a fivecountry study. Journal of Business Venturing, 17(4), 291-312. https://doi.org/10.1016/S08839026(00)00067-7

Megginson, W. L., Meles, A., Sampagnaro, G., \& Verdoliva, V. (2016). Financial distress risk in initial public offerings: How much do venture capitalists matter? Journal of Corporate Finance. https://doi.org/10.1016/j.jcorpfin.2016.09.007

Megginson, W. L., \& Weiss, K. A. (1991). Venture Capitalist Certification in Initial Public Offerings. The Journal of Finance, 46(3), 879-903. https://doi.org/10.1111/j.15406261.1991.tb03770.x

Mehran, H., \& Peristiani, S. (2010). Financial Visibility and the Decision to Go Private. Review of Financial Studies, 23(2), 519-547. https://doi.org/10.1093/rfs/hhp044

Meyer, K. E., Mudambi, R., \& Narula, R. (2011). Multinational Enterprises and Local Contexts: The Opportunities and Challenges of Multiple-Embeddedness. Journal of 
Management Studies. https://doi.org/10.1111/j.1467-6486.2010.00968.x

Migliorati, K., \& Vismara, S. (2014). Ranking Underwriters of European IPOs: Ranking Underwriters of European IPOs. European Financial Management, 20(5), 891-925. https://doi.org/10.1111/eufm.12049

Nahata, R. (2008). Venture capital reputation and investment performance约. Journal of Financial Economics, 90(2), 127-151. https://doi.org/10.1016/j.jfineco.2007.11.008

Narendranathan, W., \& Stewart, M. B. (2009). Simple Methods for Testing for the Proportionality of Cause-Specific Hazards in Competing Risks Models. Oxford Bulletin of Economics and Statistics, 53(3), 331-340. https://doi.org/10.1111/j.1468-

0084.1991.mp53003007.x

Oh, S. (2018). Fire-sale acquisitions and intra-industry contagion. Journal of Corporate Finance, 50, 265-293. https://doi.org/10.1016/j.jcorpfin.2018.04.001

Park, S., \& LiPuma, J. A. (2020). New venture internationalization: The role of venture capital types and reputation. Journal of World Business, 55(1), 101025.

https://doi.org/10.1016/j.jwb.2019.101025

Peristiani, S., \& Hong, G. (2004). Pre-IPO financial performance and aftermarket survival. Current Issues in Economics and Finance., 10(2).

Ragozzino, R. (2009). The Effects of Geographic Distance on the Foreign Acquisition Activity of U.S. Firms. Management International Review, 49(4), 509-535.

https://doi.org/10.1007/s11575-009-0006-7

Ranft, A. L., \& Lord, M. D. (2002). Acquiring new technologies and capabilities: A grounded model of acquisition implementation. Organization science, 13(4), 420-441.

Rindermann, G. (2003). Venture Capitalist Participation and the Performance of IPO Firms: Empirical Evidence from France, Germany, and the UK. SSRN Electronic Journal. https://doi.org/10.2139/ssrn.425080

Ritter, J. R. (1991). The Long-Run Performance of initial Public Offerings. The Journal of Finance, 46(1), 3-27. https://doi.org/10.1111/j.1540-6261.1991.tb03743.x

Ruckman, K. (2005). Technology sourcing through acquisitions: evidence from the US drug industry. Journal of International Business Studies, 36(1), 89-103.

Santarelli, E., \& Vivarelli, M. (2007). Entrepreneurship and the process of firms' entry, survival and growth. Industrial and Corporate Change, 16(3), 455-488.

https://doi.org/10.1093/icc/dtm010

Schultz, P. (1993). Unit initial public offerings. Journal of Financial Economics, 34(2), 199229. https://doi.org/10.1016/0304-405X(93)90018-7

Shimizu, K., Hitt, M. A., Vaidyanath, D., \& Pisano, V. (2004). Theoretical foundations of cross-border mergers and acquisitions: A review of current research and recommendations for the future. Journal of International Management, 10(3), 307-353.

https://doi.org/10.1016/j.intman.2004.05.005

Sørensen, M. (2007). How Smart Is Smart Money? A Two-Sided Matching Model of Venture Capital. The Journal of Finance, 62(6), 2725-2762. https://doi.org/10.1111/j.1540-

6261.2007.01291.x

Tykvová, T. (2006). How do investment patterns of independent and captive private equity funds differ? Evidence from Germany. Financial Markets and Portfolio Management, 20(4), 399-418. https://doi.org/10.1007/s11408-006-0036-0

Tykvová, T. (2007). How do investment patterns of independent and captive private equity funds differ? Evidence from Germany. Financial Markets and Portfolio Management, 20(4), 399-418. https://doi.org/10.1007/s11408-006-0036-0

Useche, D. (2014). Are patents signals for the IPO market? An EU-US comparison for the software industry. Research Policy, 43(8), 1299-1311.

https://doi.org/10.1016/j.respol.2014.04.004

Useche, D. (2015). Patenting Behaviour and the Survival of Newly Listed European Software 
Firms. Industry and Innovation, 22(1), 37-58.

https://doi.org/10.1080/13662716.2015.1013733

Useche, D., Miguelez, E., \& Lissoni, F. (2019). Highly skilled and well connected: Migrant inventors in cross-border M\&As. Journal of International Business Studies.

https://doi.org/10.1057/s41267-018-0203-3

Vismara, S., Paleari, S., \& Ritter, J. R. (2012). Europe's Second Markets for Small

Companies: Europe's Second Markets for Small Companies. European Financial

Management, 18(3), 352-388. https://doi.org/10.1111/j.1468-036X.2012.00641.x

Wagner, S., \& Cockburn, I. (2010). Patents and the survival of Internet-related IPOs.

Research Policy, 39(2), 214-228. https://doi.org/10.1016/j.respol.2009.12.003

Wang, X. A., \& Wan, W. P. (2013). Explaining the Variance in Underpricing among Venture Capital-Backed IPOs: A Comparison Between Private and Corporate VC Firms: Explaining the Variance in Underpricing Among VC-Backed IPOs. Strategic Entrepreneurship Journal, 7(4), 331-342. https://doi.org/10.1002/sej.1163

\section{TABLES}

Table 1: Stock market and sectorial distribution of high-tech companies

\begin{tabular}{|c|c|c|c|c|c|c|}
\hline Variable & Freq. & $\begin{array}{c}\text { Percentage } \\
(\%)\end{array}$ & $\begin{array}{c}\mathrm{N}=445 \\
\text { Non-VC }\end{array}$ & $\begin{array}{c}\mathrm{N}=155 \\
\text { IVC }\end{array}$ & $\begin{array}{c}\mathrm{N}=28 \\
\mathrm{BVC}\end{array}$ & $\begin{array}{l}\mathrm{N}=23 \\
\mathrm{CVC}\end{array}$ \\
\hline London Stock Exchange & 302 & $46.3 \%$ & $50.34 \%$ & $45.16 \%$ & $10.71 \%$ & $21.74 \%$ \\
\hline Euronext & 178 & $27.3 \%$ & 24.49 & $22.58 \%$ & $71.43 \%$ & $60.87 \%$ \\
\hline Frankfurt & 171 & $26.2 \%$ & 25.17 & $32.26 \%$ & $17.86 \%$ & $17.39 \%$ \\
\hline Total & 651 & $100 \%$ & $100 \%$ & $100 \%$ & $100 \%$ & $100 \%$ \\
\hline Pharmaceuticals and Biotechnology & 90 & $13.8 \%$ & $8.54 \%$ & $31.61 \%$ & $7.14 \%$ & $4.35 \%$ \\
\hline Health Care Equipment \& Services & 66 & $10.1 \%$ & $10.11 \%$ & $11.61 \%$ & $3.57 \%$ & $8.70 \%$ \\
\hline Technology Hardware and Equipment & 84 & $12.9 \%$ & $12.36 \%$ & $12.26 \%$ & $10.71 \%$ & $30.43 \%$ \\
\hline Computer Services & 137 & $21.0 \%$ & $26.07 \%$ & $7.74 \%$ & $21.43 \%$ & $13.04 \%$ \\
\hline Internet & 53 & $8.1 \%$ & $7.87 \%$ & $7.10 \%$ & $14.29 \%$ & $13.04 \%$ \\
\hline Software & 180 & $27.6 \%$ & $28.09 \%$ & $26.45 \%$ & $32.14 \%$ & $21.74 \%$ \\
\hline Telecom & 41 & $6.3 \%$ & $6.97 \%$ & $3.23 \%$ & $10.71 \%$ & $8.70 \%$ \\
\hline Total & 651 & $100 \%$ & $100 \%$ & $100 \%$ & $100 \%$ & $100 \%$ \\
\hline
\end{tabular}

The sample consists of 651 high-tech firms that went public between 1995 and 2012 on the stock markets of the three largest European economies: France, Germany, and the United Kingdom. We focused on two broadly defined high-tech sectors using the Industry Classification Benchmark (ICB) provided by Euronext: health care (including health care equipment and services, pharmaceuticals and biotechnology) and information and communication technology (software, internet, computer services, telecom, technology hardware and equipment). Freq. is the number of IPO firms per stock market and per sector. Percentage (\%) is the number of IPO firms divided by the total number of IPO firms in the corresponding category. Non-VC indicates the percentage of Non-VC backed firms. IVC, BVC and CVC indicate the percentage of firms backed by Independent VC, Bank-affiliated $V C$ and Corporate VC, respectively, in the corresponding category. 
Table 2: Summary statistics and Pearson Correlation matrix

\begin{tabular}{|c|c|c|c|c|c|c|c|c|c|c|}
\hline & Variable & Mean & Std. Dev. & 1 & 2 & 3 & 4 & 5 & 6 & 7 \\
\hline 1 & Exit duration $\%$ & 109.4459 & 75.03587 & 1.0000 & & & & & & \\
\hline 2 & Exit $\%$ & .6267281 & .4840453 & $-0.5246^{*}$ & 1.0000 & & & & & \\
\hline 3 & $M \& A \digamma$ & .2841782 & .4513689 & $-0.1844 *$ & $0.4863^{*}$ & 1.0000 & & & & \\
\hline 4 & Failure $\%$ & .3425499 & .4749273 & $-0.3594 *$ & $0.5571 *$ & $-0.4548^{*}$ & 1.0000 & & & \\
\hline 5 & Independent $V C$ & .2380952 & .4262452 & 0.0128 & -0.1278 & -0.1123 & -0.0235 & 1.0000 & & \\
\hline 6 & Corporate VC & .0353303 & .1847552 & -0.0175 & 0.0101 & 0.0270 & -0.0154 & -0.1070 & 1.0000 & \\
\hline 7 & Bank-affiliated VC & .0430108 & .2030373 & 0.1299 & -0.0399 & 0.0343 & -0.0733 & -0.1185 & -0.0406 & 1.0000 \\
\hline 8 & VC Reputation & .5927021 & 1.822955 & 0.0215 & -0.0466 & -0.0330 & -0.0161 & $0.4588^{*}$ & 0.1123 & 0.0310 \\
\hline 9 & Foreign VC & .1013825 & .3020666 & 0.0682 & -0.1196 & -0.0311 & -0.0923 & $0.5053^{*}$ & -0.0091 & 0.0793 \\
\hline 10 & Underwriter Reputation & .4312074 & .31786 & 0.0584 & -0.0095 & 0.0159 & -0.0247 & 0.0240 & 0.0091 & 0.0505 \\
\hline 11 & Number of VCs & .9923195 & 2.198937 & -0.0140 & -0.0851 & -0.0629 & -0.0269 & $0.5453^{*}$ & $0.1976^{*}$ & $0.1972^{*}$ \\
\hline 12 & Patent 5 years & 3.241167 & 11.36155 & 0.0103 & -0.0860 & -0.0095 & -0.0786 & $0.1638 *$ & 0.0670 & -0.0298 \\
\hline 13 & IPO proceeds & .1920123 & .3941856 & 0.0335 & 0.0188 & 0.0196 & 0.0006 & 0.1028 & 0.0692 & -0.0057 \\
\hline 14 & Total assets & .25494 & 1.635733 & 0.0083 & 0.0071 & 0.0438 & -0.0344 & 0.0458 & 0.0055 & 0.0133 \\
\hline 15 & Age at IPO & 8.989247 & 9.760905 & 0.0470 & -0.0829 & 0.0161 & -0.0998 & -0.0426 & -0.0629 & -0.0215 \\
\hline 16 & Dot-com bubble & .1966206 & .3977486 & 0.1227 & 0.0382 & 0.0396 & 0.0013 & -0.0678 & -0.0109 & -0.0287 \\
\hline \multirow[t]{2}{*}{17} & Sector entry ratio & .5808541 & .2533793 & 0.0815 & -0.0117 & 0.0152 & -0.0263 & $-0.1518 *$ & 0.0077 & 0.0682 \\
\hline & & 8 & 9 & 10 & 11 & 12 & 13 & 14 & 15 & 16 \\
\hline 8 & VC Reputation & 1.0000 & & & & & & & & \\
\hline 9 & Foreign VC & $0.3862 *$ & 1.0000 & & & & & & & \\
\hline 10 & Underwriter Reputation & 0.0484 & -0.0036 & 1.0000 & & & & & & \\
\hline 11 & Number of VCs & $0.2694 *$ & $0.4389 *$ & 0.0592 & 1.0000 & & & & & \\
\hline 12 & Patent 5 years & 0.0501 & $0.1735^{*}$ & 0.0129 & $0.2815^{*}$ & 1.0000 & & & & \\
\hline 13 & IPO proceeds & 0.0347 & 0.0202 & 0.0984 & 0.0643 & -0.0050 & 1.0000 & & & \\
\hline 14 & Total assets & 0.0822 & $0.1456^{*}$ & 0.0608 & 0.0856 & $0.1419^{*}$ & $-0.5300^{*}$ & 1.0000 & & \\
\hline 15 & Age at IPO & -0.0191 & 0.0014 & -0.0067 & -0.0360 & -0.0090 & $-0.1780^{*}$ & $0.2445^{*}$ & 1.0000 & \\
\hline & Dot-com bubble & -0.0219 & -0.0253 & 0.0823 & -0.0968 & -0.0960 & $0.1548 *$ & 0.0296 & 0.0536 & 1.0000 \\
\hline 17 & Sector entry ratio & -0.0247 & -0.0821 & 0.1247 & -0.1171 & $-0.1612 *$ & 0.1076 & -0.0108 & -0.0486 & $0.3919 *$ \\
\hline
\end{tabular}

This table shows the descriptive statistics and correlation matrix of the main variables included in the analysis. Exit duration measures the survival time in the sample (in months) which is defined as the difference between the effective exit date and the effective date of the IPO. The variables Exit, $M \& A$, and Failure are indicator variables that are equal to 1 when the IPO delists, is acquired or fails, respectively, and equals 0 otherwise. The variables Independent VC, Corporate VC, and Bankaffiliated $V C$ are indicator variables that are equal to 1 when the IPO was backed by the corresponding type of VC; it equals 0 otherwise. VC Reputation is measured by the VC firm's relative market share of completed VC-backed IPOs. Foreign VC is defined as a dummy variable that is equal to 1 if the lead $\mathrm{VC}$ operates in a different country from the portfolio company's home country, and zero otherwise. Using the underwriter ranks from Migliorati and Vismara (2014), we define Underwriter Reputation as the equally weighted market shares based on the number of IPOs managed. Number of VCs is the number of VC investors that support the company before IPO. Patent 5 years is the number of patent applications submitted by the firm in the five years before the IPO. IPO proceeds is the log-transformed variable of the amount of money raised during the IPO process divided by the company's total assets in the year preceding IPO. Total assets is the log-transformed variable of total assets in the year preceding IPO. Age at IPO is calculated as the difference between the effective date of the IPO and the date of legal incorporation. The variable Dot-com bubble is equal to 1 if the company was quoted in 1999 or 2000, and is 0 otherwise. Sector entry ratio is measured as the number of high-tech companies going public per sector using the one-digit ICB classification, divided by the total number of high-tech IPOs in a given year. * indicates significance at the 5\% level and $\dagger$ indicates the dependent variables. 


\section{Table 3: Descriptive statistics for the sample of VC-backed and non-VC-backed companies and for the three groups of VCs}

\begin{tabular}{|c|c|c|c|c|c|c|c|c|}
\hline Variable & $\begin{array}{c}\text { Non-VC- } \\
\text { backed } \\
\text { (mean) }\end{array}$ & $\begin{array}{c}\begin{array}{c}\text { VC- } \\
\text { backed }\end{array} \\
\text { (mean) }\end{array}$ & $\begin{array}{c}\text { IVC } \\
\text { (mean) }\end{array}$ & $\begin{array}{c}\text { CVC } \\
\text { (mean) }\end{array}$ & $\begin{array}{c}\text { BVC } \\
\text { (mean) }\end{array}$ & $\begin{array}{c}\text { IVC } \\
\text { versus } \\
\text { BVC } \\
\text { (ttest) }\end{array}$ & $\begin{array}{c}\text { IVC } \\
\text { versus } \\
\text { CVC } \\
\text { (ttest) }\end{array}$ & $\begin{array}{c}\text { CVC } \\
\text { versus } \\
\text { BVC } \\
\text { (ttest) }\end{array}$ \\
\hline & 1 & 2 & 3 & 4 & 5 & 6 & 7 & 8 \\
\hline Exit duration (in months) $\%$ & 106.313 & 116.213 & 111.159 & 102.588 & $155.381 *$ & $*$ & & \\
\hline Exit $\%$ & 0.670 & $0.533^{*}$ & $0.516^{*}$ & 0.652 & 0.536 & & & \\
\hline$M \& A \digamma$ & 0.308 & 0.233 & $0.193^{*}$ & 0.348 & 0.357 & & & \\
\hline Failure $\%$ & 0.362 & 0.301 & 0.322 & 0.304 & $0.178 *$ & & & \\
\hline$V C$ reputation & 0.000 & $1.873^{*}$ & $2.088^{*}$ & $1.661^{*}$ & $0.859 *$ & $*$ & & $*$ \\
\hline Foreign VC & 0.000 & $0.334 *$ & $0.374 *$ & $0.217^{*}$ & $0.214 *$ & & & \\
\hline Underwriter Reputation & 0.421 & 0.453 & 0.445 & 0.446 & 0.507 & & & \\
\hline Number of VCs & 0.000 & $3.136^{*}$ & $3.135^{*}$ & $3.261 *$ & $3.036^{*}$ & & & \\
\hline Patent 5 years & 1.977 & $5.971^{*}$ & $6.568^{*}$ & $7.217^{*}$ & 1.643 & & & \\
\hline IPO proceeds & 0.122 & $0.541^{*}$ & $0.555^{*}$ & $0.846^{*}$ & 0.211 & & & \\
\hline Total assets & 16.251 & 16.430 & 16.444 & 16.356 & 16.412 & & & \\
\hline Age at IPO (in years) & 9.476 & 7.937 & 8.245 & 5.783 & 8.000 & & & \\
\hline Dot-com bubble & 0.218 & $0.150 *$ & 0.148 & 0.174 & 0.143 & & & \\
\hline Sector entry ratio & 0.599 & $0.541^{*}$ & $0.512^{*}$ & 0.591 & 0.662 & $*$ & & \\
\hline
\end{tabular}

Legend: Columns 1 and 2 give the mean of each variable for non-VC-backed firms and VC-backed firms, respectively. Columns 3, 4 and 5, give the mean of each variable for the different types of VC-backed firms. For Columns 2 to 8 , we conducted t-tests to test for differences in the means of different groups and marked $*$ if the difference is statistically significant at the 5\% level. For Columns 2 to 5, we conducted a standard two-sided t-test to test for differences between each group of VC-backed firms and the group of non-VC-backed firms. For instance, the mean values for the variables Patent 5 years and IPO proceeds are larger and statistically significant at the 5\% level for VC-backed firms relative to non-VC-backed firms (Column 2). In contrast, the mean values of Exit, Dot-com bubble and Sector entry ratio are lower and statistically significant at the 5\% level for VC-backed firms relative to non-VC-backed firms (Column 2). In Columns 6, 7 and 8, the ttest tested the differences in the means for IVC- versus BVC-backed companies, for IVC- versus CVC-backed companies and for CVC- versus BVC-backed companies, respectively. * indicates that the difference is significant at the $5 \%$ level $(\mathrm{p}<0.05)$ and $\dagger$ indicates the dependent variables. 
Figure 1: Kaplan-Meier survival curves of VC-backed and non-VC-backed companies

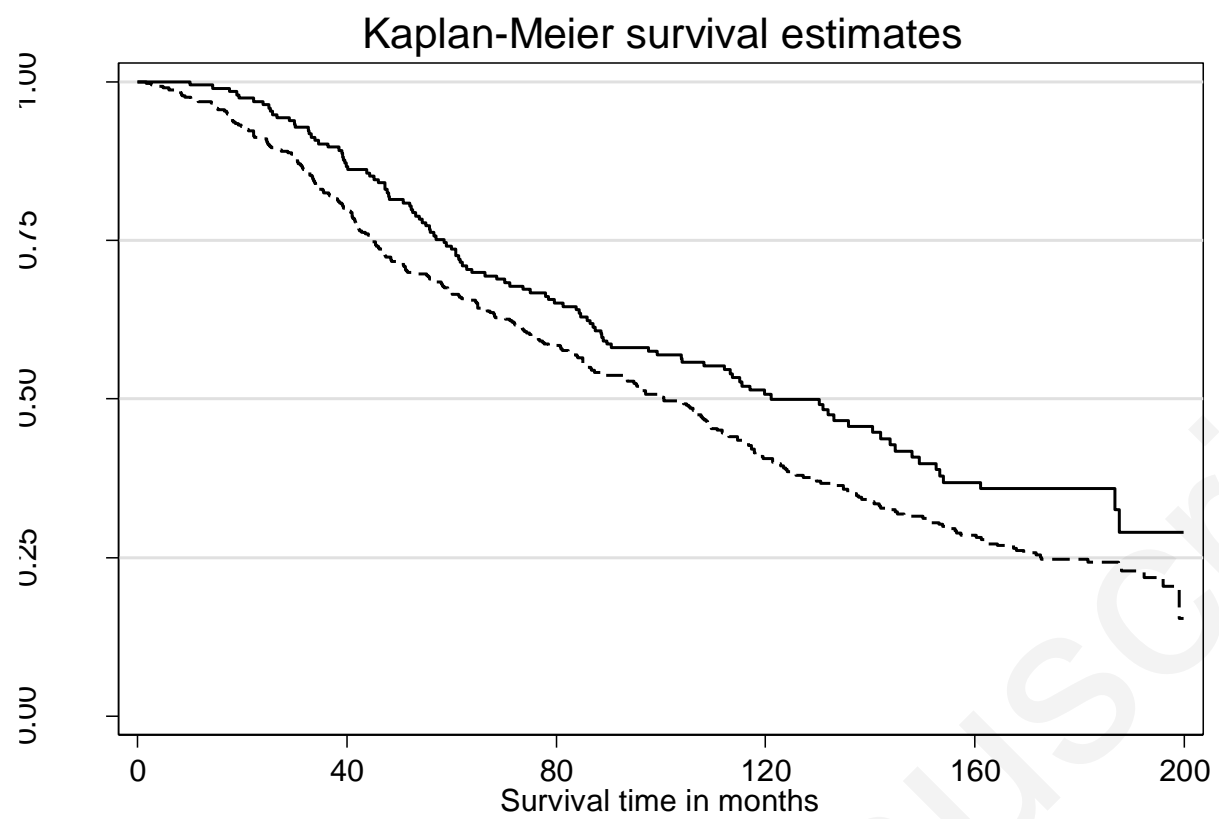

Fig. 1. Kaplan-Meier survival curves for the firms in our sample. The figure shows survival curves for (-) VCbacked firms and (- - -) non-VC-backed firms

Figure 2: Kaplan-Meier survival curves for the companies by type of VC firm.

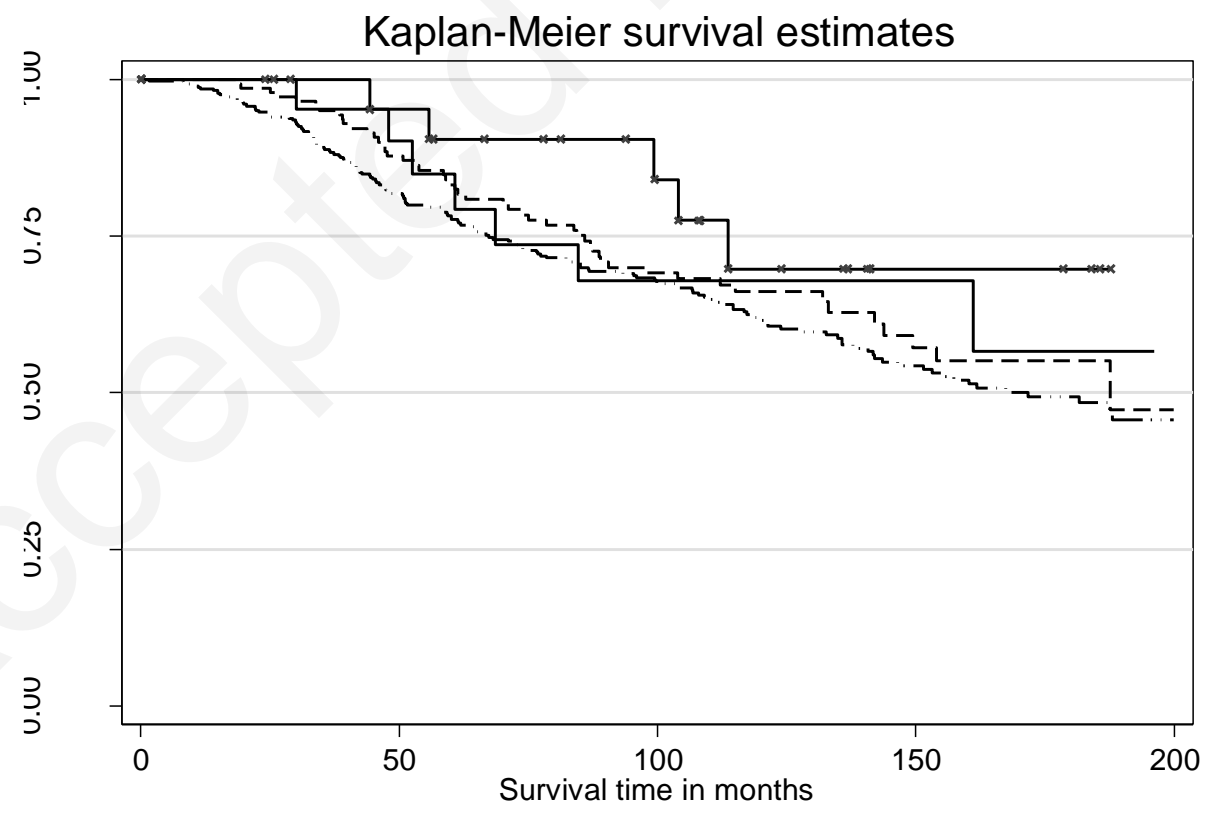

Fig. 2. Kaplan-Meier survival curves for the firms in our sample. The figure shows survival curves by VC type with (_. . _) non-VC-backed firms, (- - -) IVC-backed firms, (-) CVC-backed firms and (-x-) BVC-backed firms 
Table 4: Multivariate analysis for pooled and competing risk models for types of VCs and forms of delisting

\begin{tabular}{|c|c|c|c|c|}
\hline \multirow{3}{*}{ VARIABLES } & \multicolumn{4}{|c|}{ Type of Delisting } \\
\hline & Delisting & Failure & $\begin{array}{c}\text { Intra-EU } \\
\text { M\&As }\end{array}$ & $\begin{array}{c}\text { Extra-EU } \\
\text { M\&As }\end{array}$ \\
\hline & 1 & 2 & 3 & 4 \\
\hline \multirow[t]{2}{*}{ Independent VC } & $-0.466 * *$ & $-0.437 * * *$ & -0.491 & -0.708 \\
\hline & $(0.160)$ & $(0.121)$ & $(0.271)$ & $(0.454)$ \\
\hline \multirow[t]{2}{*}{ Corporate VC } & -0.127 & -0.554 & -0.511 & $1.176^{* * *}$ \\
\hline & $(0.239)$ & $(0.344)$ & $(0.360)$ & $(0.174)$ \\
\hline \multirow[t]{2}{*}{ Bank-affiliated VC } & -0.503 & $-1.170 * * *$ & 0.0954 & 0.252 \\
\hline & $(0.334)$ & $(0.295)$ & $(0.334)$ & $(0.454)$ \\
\hline \multirow[t]{2}{*}{$V C$ reputation } & 0.0272 & 0.0539 & -0.0751 & 0.129 \\
\hline & $(0.0170)$ & $(0.0353)$ & $(0.101)$ & $(0.0998)$ \\
\hline \multirow[t]{2}{*}{ Foreign VC } & -0.401 & $-0.817 * * *$ & 0.0837 & -0.0473 \\
\hline & $(0.242)$ & $(0.222)$ & $(0.685)$ & $(0.459)$ \\
\hline \multirow[t]{2}{*}{ Underwriter Reputation } & 0.0178 & -0.120 & 0.396 & $-0.194 * * *$ \\
\hline & $(0.102)$ & $(0.192)$ & $(0.588)$ & $(0.0508)$ \\
\hline \multirow[t]{2}{*}{ Number of VCs } & 0.0746 & $0.133 * * *$ & -0.0745 & 0.114 \\
\hline & $(0.0413)$ & $(0.0307)$ & $(0.0502)$ & $(0.0744)$ \\
\hline \multirow[t]{2}{*}{ Patent 5 years } & $-0.00920 * * *$ & $-0.0374 * *$ & $-1.75 e-05$ & 0.00674 \\
\hline & $(0.00264)$ & $(0.0140)$ & $(0.00409)$ & $(0.00562)$ \\
\hline \multirow[t]{2}{*}{ IPO proceeds } & 0.000850 & -0.0230 & 0.0380 & $0.102 * * *$ \\
\hline & $(0.00289)$ & $(0.0320)$ & $(0.0642)$ & $(0.0124)$ \\
\hline \multirow[t]{2}{*}{ Total assets } & 0.0341 & -0.00550 & $0.0817 * *$ & $0.208 * * *$ \\
\hline & $(0.0191)$ & $(0.0206)$ & $(0.0278)$ & $(0.0131)$ \\
\hline \multirow[t]{2}{*}{ Age at IPO } & $-0.0136 * * *$ & -0.0222 & -0.0140 & -0.00672 \\
\hline & $(0.00342)$ & $(0.0150)$ & $(0.0105)$ & $(0.0116)$ \\
\hline \multirow[t]{2}{*}{ Dot-com bubble } & 0.244 & 0.697 & -0.460 & -0.675 \\
\hline & $(0.429)$ & $(0.571)$ & $(0.408)$ & $(1.216)$ \\
\hline \multirow[t]{2}{*}{ Sector entry ratio } & 0.0731 & 0.551 & -0.926 & 0.459 \\
\hline & $(0.0472)$ & $(0.531)$ & $(0.584)$ & (1.006) \\
\hline Observations & 651 & 651 & 651 & 651 \\
\hline Year FE & YES & YES & YES & YES \\
\hline Business segment FE & YES & YES & YES & YES \\
\hline Stock Market FE & YES & YES & YES & YES \\
\hline Country FE & YES & YES & YES & YES \\
\hline Number of delistings & 408 & 223 & 122 & 63 \\
\hline Log pseudolikelihood & -2356 & -1269 & -683.1 & -337.6 \\
\hline Risk & 71249 & 71249 & 71249 & 71249 \\
\hline
\end{tabular}

This table shows the results from the competing risk analysis. The sample consists of 651 IPO firms in the period from 1995 to 2012. The time to failure is the number of months between the IPO date and the date in which the company is delisted from the stock markets. See Table 2 for definitions of the independent variables. We report here the coefficient for the variables. A negative coefficient (hazard ratio lower than 1) indicates that the variable has a positive impact on the duration (that is, it increases the probability of survival and thus it decreases the probability of exiting the market). In Column 1, we show the estimation results from the pooled model (Cox PH Regression), which does not distinguish between modes of delisting. In Columns 2, 3 and 4, we present the results from the competing risk models which distinguish between delisting 
due to failure (Column 2) and delisting due to intra-EU M\&As (Column 3) and extra-EU M\&As (Column 4). Intra-EU M\&As includes domestic acquisitions (e.g., a French company buying in France), as well as cross-border acquisitions within Europe (e.g., a French company buying in Germany or the UK). Extra-EU M\&As includes companies outside of Europe buying European companies (e.g., a US company buying in Germany or the UK). Our model specifications include robust variance estimates with an added adjustment for clustering at the stock market level. ${ }^{* * *} \mathrm{p}<0.001,{ }^{* *} \mathrm{p}<0.01,{ }^{*} \mathrm{p}<0.05$

\section{Supplementary material}

\section{Appendix 1: Sample consolidation}

Information from the EURIPO database was completed and verified using financial documents publicly available on company websites and specialized websites such as Listofcompanies.co, FE Investegate for UK companies, and Bloomberg Business week, among others. For instance, if the date of incorporation or the date of delisting up to December 31, 2015 was not available from the EURIPO database, the information was obtained from the Amadeus database ${ }^{\circledR}$ (from Bureau van Dijk), from publicly available financial documents on the company website or through specialist magazines. In addition, we searched the web for companies that had been acquired in order to obtain more detail on several business cases. We also searched the web (on firms' websites and specialist websites) for companies that survived, in order to check whether they continued to operate in the financial markets.

\section{Appendix 2: Test to detect the correct model specification and proportionality assumption}

Cox PH models assume that the hazard ratio is constant over time. In the presence of hazards that do not satisfy the proportionality assumption, the estimates can give biased and unreliable results for all the parameters. For that reason it is important to evaluate potential specification errors (Keele 2010) and the validity of the proportionality assumption through several types of tests (Grambsch and Therneau 1994).

For this purpose, we first implemented a test for PH through a nonzero slope in a generalized linear regression of the scaled Schoenfeld residuals on time. In this test, the null hypothesis of zero slope is equivalent to testing that the log hazard-ratio is constant across time (Grambsch and Therneau 1994). We implemented these tests while considering competing risk specifications. These tests suggest that the PH assumption has not been violated at the 5\% level (See Table 1A). 
Table 1A: Testing the PH assumption

\begin{tabular}{|c|c|c|c|c|c|c|c|c|}
\hline \multirow[b]{2}{*}{ VARIABLES } & \multicolumn{2}{|c|}{ Delisting } & \multicolumn{2}{|c|}{ Failure } & \multicolumn{2}{|c|}{ Intra-EU M\&A } & \multicolumn{2}{|c|}{ Extra-EU M\&A } \\
\hline & rho & Prob>chi 2 & rho & Prob >chi 2 & rho & Prob>chi2 & rho & Prob $>$ chi 2 \\
\hline Independent VC & -0.01417 & 0.2767 & 0.01083 & 0.5148 & 0.05651 & 0.0723 & 0.03223 & 0.3292 \\
\hline Corporate VC & -0.00433 & 0.7834 & -0.00660 & 0.7359 & 0.00781 & 0.6584 & 0.04063 & 0.2164 \\
\hline Bank-affiliated VC & -0.01485 & 0.2613 & 0.01448 & 0.3749 & 0.05682 & 0.0798 & 0.01605 & 0.6444 \\
\hline VC reputation & 0.00952 & 0.4944 & 0.00014 & 0.9938 & 0.01264 & 0.4343 & -0.02843 & 0.3962 \\
\hline Foreign VC & -0.00852 & 0.5508 & -0.01809 & 0.2683 & -0.00083 & 0.9595 & 0.04035 & 0.2062 \\
\hline $\begin{array}{l}\text { Underwriter } \\
\text { Reputation }\end{array}$ & -0.008 & 4 & 0.00611 & ( 7244 & 0.01205 & 0.4551 & 0.02693 & .4387 \\
\hline Number of VCs & 0.00703 & 0.6348 & 0.02103 & 0.3035 & -0.02971 & 0.1292 & -0.04542 & 0.1475 \\
\hline Patent 5 years & -0.01368 & 0.2923 & -0.01084 & 0.5146 & 0.03475 & 0.1020 & -0.04508 & 0.1562 \\
\hline IPO proceeds & -0.00808 & 0.5755 & 0.00317 & 0.8590 & 0.00722 & 0.6514 & -0.00007 & 0.9983 \\
\hline Total assets & -0.01382 & 0.2875 & 0.02159 & 0.2029 & -0.00826 & 0.6054 & -0.01039 & 0.7678 \\
\hline Age at IPO & 0.00802 & 0.6555 & -0.01588 & 0.3292 & -0.01307 & 0.4198 & 0.04387 & 0.1633 \\
\hline Dot-com bubble & -0.01262 & 0.3348 & 0.00082 & 0.9641 & -0.02081 & 0.2294 & -0.04544 & 0.1513 \\
\hline Sector entry ratio & 0.01165 & 0.5047 & -0.01232 & 0.4543 & 0.04637 & 0.1170 & 0.04579 & 0.1452 \\
\hline Year FE & YES & YES & YES & YES & YES & YES & YES & YES \\
\hline $\begin{array}{c}\text { Business segment } \\
F E\end{array}$ & YES & YES & YES & YES & YES & YES & YES & YES \\
\hline Stock Market FE & YES & YES & YES & YES & YES & YES & YES & YES \\
\hline Country FE & YES & YES & YES & YES & YES & YES & YES & YES \\
\hline Global test & & 0.7353 & & 0.4243 & & 0.3505 & & 0.3458 \\
\hline
\end{tabular}

This table evaluates the validity of the proportionality assumption. We implemented a test of proportional-hazards assumption through a nonzero slope in a generalized linear regression of the scaled Schoenfeld residuals on time. In this test, the null hypothesis of zero slope is equivalent to testing that the log hazard-ratio is constant across time. These tests suggest that the proportional-hazards assumption has not been violated at the $5 \%$ level (Prob $>\operatorname{chi} 2>0.05)$

Considering the competing risk specification, we also implemented an additional test. Narendranathan and Stewart (2009) provide a test of whether exits to different states are behaviorally distinct (rather than simply incidental) for continuous-time PH models. This is a test of the hypothesis that the cause-specific hazards are all proportional to one another (i.e., that all parameters except the intercepts are equal across the hazards). For our basic model reported in Table 4, we can reject the null hypothesis of risk proportionality at $1 \%$ significance (TS $=932.3$ ). Hence, we reject the hypothesis that the different forms of exit are behaviorally equal. 


\section{Appendix 3: Robustness check: alternative duration model}

Table 2A: Weibull duration model

\begin{tabular}{|c|c|c|c|c|}
\hline VARIABLES & $\begin{array}{c}(1) \\
\text { Delisting }\end{array}$ & $\begin{array}{l}\quad(2) \\
\text { Failure }\end{array}$ & $\begin{array}{c}(3) \\
\text { Intra-EU } \\
\text { M\&As }\end{array}$ & $\begin{array}{c}(4) \\
\text { Extra-EU } \\
\text { M\&As }\end{array}$ \\
\hline Independent $V C$ & $\begin{array}{c}-0.512^{* *} \\
(0.156)\end{array}$ & $\begin{array}{c}-0.484 * * * \\
(0.112)\end{array}$ & $\begin{array}{l}-0.527 * \\
(0.227)\end{array}$ & $\begin{array}{l}-0.754 \\
(0.468)\end{array}$ \\
\hline Corporate $V C$ & $\begin{array}{l}-0.161 \\
(0.307)\end{array}$ & $\begin{array}{l}-0.608 \\
(0.404)\end{array}$ & $\begin{array}{l}-0.511 \\
(0.373)\end{array}$ & $\begin{array}{c}1.153 * * * \\
(0.205)\end{array}$ \\
\hline Bank-affiliated VC & $\begin{array}{c}-0.919 * * \\
(0.285)\end{array}$ & $\begin{array}{c}-1.654 * * * \\
(0.199)\end{array}$ & $\begin{array}{l}-0.328 \\
(0.270)\end{array}$ & $\begin{array}{l}0.0150 \\
(0.461)\end{array}$ \\
\hline$V C$ reputation & $\begin{array}{c}0.0282 \\
(0.0178)\end{array}$ & $\begin{array}{c}0.0577 \\
(0.0340)\end{array}$ & $\begin{array}{l}-0.0796 \\
(0.0990)\end{array}$ & $\begin{array}{c}0.133 \\
(0.100)\end{array}$ \\
\hline Foreign VC & $\begin{array}{l}-0.396 \\
(0.239)\end{array}$ & $\begin{array}{c}-0.845^{* * *} \\
(0.194)\end{array}$ & $\begin{array}{c}0.128 \\
(0.694)\end{array}$ & $\begin{array}{l}-0.0432 \\
(0.459)\end{array}$ \\
\hline Underwriter Reputation & $\begin{array}{l}-0.0251 \\
(0.115)\end{array}$ & $\begin{array}{l}-0.149 \\
(0.178)\end{array}$ & $\begin{array}{c}0.346 \\
(0.614)\end{array}$ & $\begin{array}{c}-0.250 * * * \\
(0.0639)\end{array}$ \\
\hline Number of VCs & $\begin{array}{c}0.0900 \\
(0.0480)\end{array}$ & $\begin{array}{c}0.151 * * * \\
(0.0357)\end{array}$ & $\begin{array}{l}-0.0587 \\
(0.0359)\end{array}$ & $\begin{array}{c}0.125 \\
(0.0823)\end{array}$ \\
\hline Patent 5 years & $\begin{array}{c}-0.0103 * * * \\
(0.00238)\end{array}$ & $\begin{array}{l}-0.0391 * \\
(0.0159)\end{array}$ & $\begin{array}{r}-0.000804 \\
(0.00376)\end{array}$ & $\begin{array}{c}0.00575 \\
(0.00485)\end{array}$ \\
\hline IPO proceeds & $\begin{array}{c}0.00444 \\
(0.00496)\end{array}$ & $\begin{array}{l}-0.0165 \\
(0.0347)\end{array}$ & $\begin{array}{c}0.0353 \\
(0.0593)\end{array}$ & $\begin{array}{l}0.113 * * * \\
(0.00814)\end{array}$ \\
\hline Total assets & $\begin{array}{c}0.0437 \\
(0.0226)\end{array}$ & $\begin{array}{l}0.00594 \\
(0.0211)\end{array}$ & $\begin{array}{l}0.0862 * \\
(0.0344)\end{array}$ & $\begin{array}{c}0.223 * * * \\
(0.0136)\end{array}$ \\
\hline Age at IPO & $\begin{array}{c}-0.0134 * * * \\
(0.00242)\end{array}$ & $\begin{array}{l}-0.0227 \\
(0.0149)\end{array}$ & $\begin{array}{c}-0.0117 \\
(0.00979)\end{array}$ & $\begin{array}{r}-0.00623 \\
(0.0113)\end{array}$ \\
\hline Dot-com bubble & $\begin{array}{c}0.281 \\
(0.440)\end{array}$ & $\begin{array}{c}0.766 \\
(0.582)\end{array}$ & $\begin{array}{l}-0.425 \\
(0.397)\end{array}$ & $\begin{array}{l}-0.697 \\
(1.227)\end{array}$ \\
\hline Sector entry ratio & $\begin{array}{c}0.231 * * * \\
(0.0415)\end{array}$ & $\begin{array}{c}0.762 \\
(0.587)\end{array}$ & $\begin{array}{l}-0.736 \\
(0.680)\end{array}$ & $\begin{array}{c}0.521 \\
(1.015)\end{array}$ \\
\hline Constant & $\begin{array}{c}-5.572 * * * \\
(0.764)\end{array}$ & $\begin{array}{c}-5.466 * * * \\
(0.519)\end{array}$ & $\begin{array}{c}-22.40 * * * \\
(1.076)\end{array}$ & $\begin{array}{c}-24.88 * * * \\
(1.336)\end{array}$ \\
\hline Observations & 651 & 651 & 651 & 651 \\
\hline Number of delistings & 408 & 223 & 122 & 63 \\
\hline Year FE & YES & YES & YES & YES \\
\hline Business segment FE & YES & YES & YES & YES \\
\hline Stock Market FE & YES & YES & YES & YES \\
\hline Country FE & YES & YES & YES & YES \\
\hline $\ln \_p$ & $\begin{array}{c}0.277 * * * \\
(0.0182)\end{array}$ & $\begin{array}{c}0.292 * * * \\
(0.0353)\end{array}$ & $\begin{array}{c}0.228 * * * \\
(0.0570)\end{array}$ & $\begin{array}{c}0.370 * * * \\
(0.0785)\end{array}$ \\
\hline
\end{tabular}

This table shows the results from the competing risk analysis for the Weibull model. The sample consists of 651 IPO firms in the period from 1995 to 2012. See Table 2 for definitions of both the dependent and independent variables. We report here the coefficient for the variables. A negative coefficient indicates that the variable has a positive impact on the duration (that is, it increases the probability of survival and thus it decreases the probability of exiting the market). In Column 1, we show the estimation results from the pooled model which does not distinguish between modes of delisting. In Columns 2, 3 and 4, we present the results from the competing risk models which distinguish between delisting due to business failure (Column 2) and delisting due to Intra-EU M\&As with acquirers located within Europe (Column 3) and Extra-EU M\&As with acquirers located outside Europe (Column 4). Our model specifications include robust variance estimates with an added adjustment for clustering at the stock market level. *** $\mathrm{p}<0.001, * * \mathrm{p}<0.01, * \mathrm{p}<0.05$ 